\title{
Fatal Unintentional Farm Injuries Among Persons Less Than 20 Years of Age in the United States:
}

Geographic Profiles

Nelson Adekoya, DrPH

Stephanie G. Pratt, MA

DEPARTMENT OF HEALTH AND HUMAN SERVICES

Centers for Disease Control and Prevention

National Institute for Occupational Safety and Health

July 2001 


\section{DISCLAIMER}

Mention of any company or product does not constitute endorsement by the

National Institute for Occupational Safety and Health

This document is in the public domain and may be freely copied or reprinted.

Copies of this and other NIOSH documents are available from:

Publications Dissemination, EID

National Institute for Occupational Safety and Health 4676 Columbia Parkway

Cincinnati, OH 45226-1998

Fax number: (513) 533-8573

Telephone number: 1-800-35-NIOSH (1-800-356-4674)

E-mail:pubstaft@cdc.gov

For further information about occupational safety and health topics, call 1-800-35-NIOSH (1-800-356-4674), or visit the NIOSH Website at www.cdc.gov/niosh.

Cover photograph (C) Corbis Corporation/Peter Beck, 2001. 


\section{Foreword}

More than two million youth less than 20 years of age are potentially exposed to farm safety hazards each year-as farm residents, farm family workers, hired workers, children of migrant or seasonal workers, or farm visitors. Youth on farms may be exposed to a wide range of hazards, including machinery, electric current, firearms, bodies of water, grain storage facilities, and livestock. As a place of work and a place of residence, the farm presents unique challenges for injury prevention.

The NIOSH Childhood Agricultural Injury Prevention Initiative seeks to prevent farm injuries from work and nonwork-related exposures through a comprehensive program of surveillance, research, and partnership. In keeping with the breadth of the Initiative, this document presents data by state, Census region, and Census division for all youth fatalities on U.S. farms between 1982 and 1996. These data, drawn from the Vital Statistics Mortality files of the National Center for Health Statistics, indicate that nearly 2,200 youth were fatally injured on farms during this 15 -year period, and that the leading causes of death varied considerably across geographic areas.

Although farm fatalities among youth have decreased markedly over the years, the toll remains too high. We hope this document will serve as a valuable resource to government agencies at all levels, policy makers, health and safety professionals and farm safety advocates in their efforts to develop focused and coordinated strategies to prevent youth injuries on farms.

Kathleen M. Rest, Ph.D., M.P.A.

Acting Director

National Institute for Occupational

Safety and Health 



\section{Contents}

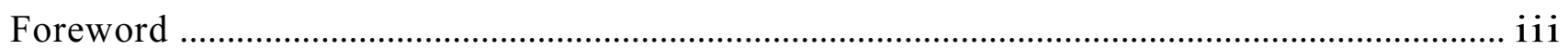

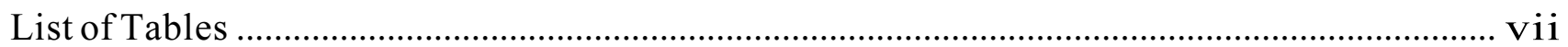

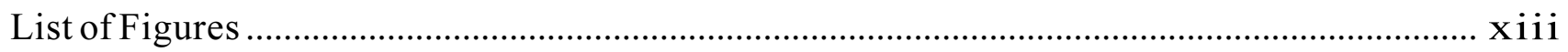

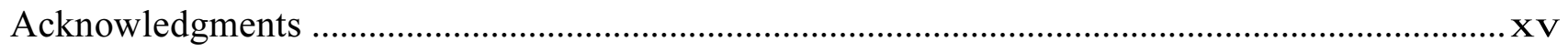

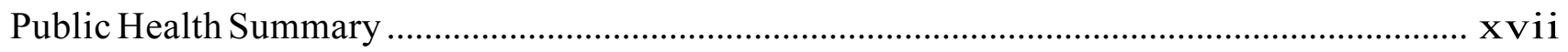

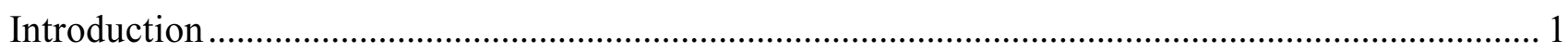

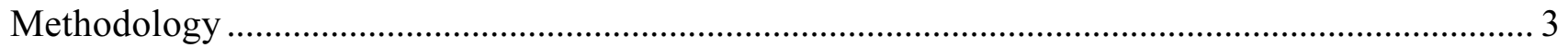

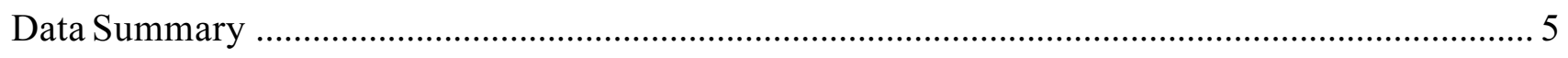

Prevention of Childhood Farm Fatalities ............................................................................ 7

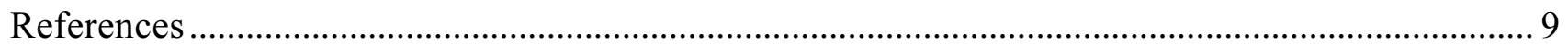

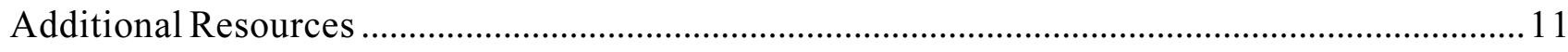

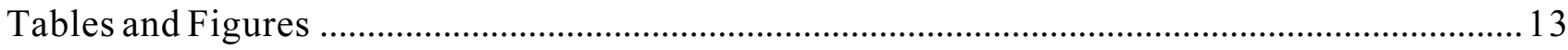

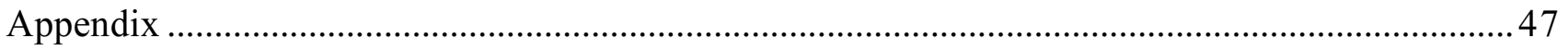





\section{List of Tables}

\section{National Data}

Table 1. Fatal farm injuries to persons less than 20 years, by year and age group, United States, 1982-1996

Table 2. Fatal farm injuries to persons less than 20 years, by gender and age group, United States, 1982-1996

Table 3. Percentage change in average annual number of fatal farm injuries to persons less than 20 years, by age group, United States, 1982-1989 and 1990-1996

Table 4. Causes of fatal farm injuries to persons less than 20 years,

United States, 1982-1996

Table 5. Causes of fatal farm injuries to persons less than 20 years, by gender,

United States, 1982-1996

Table 6. Causes of fatal farm injuries to persons less than 20 years, by age group,

United States, 1982-1996 16

Table 7. Causes of fatal farm injuries to males less than 20 years, by age group, United States, 1982-1996

Table 8. Causes of fatal farm injuries to females less than 20 years, by age group, United States, 1982-1996 18

Table 9. Percentage change in average annual number of fatal farm injuries to persons less than 20 years due to machinery, drowning, and firearms, by age group, United States, 1982-1989 and 1990-1996

\section{Data by Census Region}

Table 10. Fatal farm injuries to persons less than 20 years, by Census region and age group, United States, 1982-1996

Table 11. Percentage change in average annual number of fatal farm injuries to persons less than 20 years from all causes, by age group, Northeast Region, 1982-1989 and 1990-1996

Table 12. Percentage change in average annual number of fatal farm injuries to persons less than 20 years due to machinery, by age group, Northeast Region, 1982-1989 and 1990-1996 
Table 13. Percentage change in average annual number of fatal farm injuries to persons less than 20 years from all causes, by age group, Midwest Region, 1982-1989 and 1990-1996

Table 14. Percentage change in average annual number of fatal farm injuries to persons less than 20 years due to machinery and drowning, by age group, Midwest Region, 1982-1989 and1990-1996

Table 15. Percentage change in average annual number of fatal farm injuries to persons less than 20 years from all causes, by age group, South Region, 1982-1989 and 1990-1996

Table 16. Percentage change in average annual number of fatal farm injuries to persons less than 20 years due to machinery and drowning, by age group, South Region, 1982-1989 and 1990-1996

Table 17. Percentage change in average annual number of fatal farm injuries to persons less than 20 years from all causes, by age group, West Region, 1982-1989 and 1990-1996

Table 18. Percentage change in average annual number of fatal farm injuries to persons less than 20 years due to machinery, by age group, West Region, 1982-1989 and 1990-1996

\section{Data by Census Division}

Table 19. Fatal farm injuries to persons less than 20 years, by Census division and gender, United States, 1982-1996

Table 20. Fatal farm injuries to persons less than 20 years, by age group and Census division, United States, 1982-1996

Table 21. Causes of fatal farm injuries to persons less than 20 years, by Census division, United States, 1982-1996 26

\section{State Data}

Table 22. Fatal farm injuries to persons less than 20 years by age group and state, 1982-1996 28

Table 23. Fatal farm injuries to persons less than 20 years of age, by cause and state, 1982-1996 


\section{State Profiles}

Table 24. Leading causes of fatal farm injuries to persons less than 20 years, Alabama, 1982-1996

Table 25. Leading causes of fatal farm injuries to persons less than 20 years, Arizona, 1982-1996

Table 26. Leading causes of fatal farm injuries to persons less than 20 years, Arkansas, 1982-1996

Table 27. Leading causes of fatal farm injuries to persons less than 20 years, California, 1982-1996

Table 28. Leading causes of fatal farm injuries to persons less than 20 years, Colorado, 1982-1996 33

Table 29. Leading causes of fatal farm injuries to persons less than 20 years, Florida, 1982-1996

Table 30. Leading causes of fatal farm injuries to persons less than 20 years, Georgia, 1982-1996

Table 31. Leading causes of fatal farm injuries to persons less than 20 years, Idaho, 1982-1996

Table 32. Leading causes of fatal farm injuries to persons less than 20 years, Illinois, 1982-1996 34

Table 33. Leading causes of fatal farm injuries to persons less than 20 years, Indiana, 1982-1996 35

Table 34. Leading causes of fatal farm injuries to persons less than 20 years, Iowa, 1982-1996

Table 35. Leading causes of fatal farm injuries to persons less than 20 years,

Kansas, 1982-1996

Table 36. Leading causes of fatal farm injuries to persons less than 20 years,

Kentucky, 1982-1996

Table 37. Leading causes of fatal farm injuries to persons less than 20 years,

Louisiana, 1982-1996

Table 38. Leading causes of fatal farm injuries to persons less than 20 years,

Michigan, 1982-1996 
Table 39. Leading causes of fatal farm injuries to persons less than 20 years, Minnesota, 1982-1996

Table 40. Leading causes of fatal farm injuries to persons less than 20 years, Mississippi, 1982-1996.

Table 41. Leading causes of fatal farm injuries to persons less than 20 years, Missouri, 1982-1996.... 38

Table 42. Leading causes of fatal farm injuries to persons less than 20 years, Montana, 1982-1996 38

Table 43. Leading causes of fatal farm injuries to persons less than 20 years, Nebraska, 1982-1996. 38

Table 44. Leading causes of fatal farm injuries to persons less than 20 years, New Mexico, 1982-1996

Table 45. Leading causes of fatal farm injuries to persons less than 20 years, New York, 1982-1996

Table 46. Leading causes of fatal farm injuries to persons less than 20 years, North Carolina, 1982-1996

Table 47. Leading causes of fatal farm injuries to persons less than 20 years, North Dakota, 1982-1996.

Table 48. Leading causes of fatal farm injuries to persons less than 20 years, Ohio, 1982-1996 40

Table 49. Leading causes of fatal farm injuries to persons less than 20 years, Oklahoma, 1982-1996

Table 50. Leading causes of fatal farm injuries to persons less than 20 years, Oregon, 1982-1996....

Table 51. Leading causes of fatal farm injuries to persons less than 20 years, Pennsylvania, 1982-1996

Table 52. Leading causes of fatal farm injuries to persons less than 20 years, South Carolina, 1982-1996

Table 53. Leading causes of fatal farm injuries to persons less than 20 years, South Dakota, 1982-1996

Table 54. Leading causes of fatal farm injuries to persons less than 20 years, Tennessee, 1982-1996 
Table 55. Leading causes of fatal farm injuries to persons less than 20 years, Texas, 1982-1996

Table 56. Leading causes of fatal farm injuries to persons less than 20 years, Utah, 1982-1996

Table 57. Leading causes of fatal farm injuries to persons less than 20 years, Vermont, 1982-1996 43

Table 58. Leading causes of fatal farm injuries to persons less than 20 years, Virginia, 1982-1996 44

Table 59. Leading causes of fatal farm injuries to persons less than 20 years, Washington, 1982-1996 44

Table 60. Leading causes of fatal farm injuries to persons less than 20 years, West Virginia, 1982-1996 44

Table 61. Leading causes of fatal farm injuries to persons less than 20 years, Wisconsin, 1982-1996 45

Table 62. Leading causes of fatal farm injuries to persons less than 20 years, Wyoming, 1982-1996 



\section{List of Figures}

Figure 1. Trend of fatal farm injuries to persons less than 20 years, by age group, United States, 1982-1996

Figure 2. Trend of the leading causes of fatal farm injuries to persons less than 20 years, United States, 1982-1996

Figure 3. Map of the United States showing Census regions, Census divisions, and states ..... 19

Figure 4. Trend of the leading causes of fatal farm injuries to persons less than 20 years, Northeast Region, 1982-1996

Figure 5. Trend of the leading causes of fatal farm injuries to persons less than 20 years, Midwest Region, 1982-1996

Figure 6. Trend of the leading causes of fatal farm injuries to persons less than 20 years, South Region, 1982-1996

Figure 7. Trend of the leading causes of fatal farm injuries to persons less than 20 years, West Region, 1982-1996

Figure 8. Leading cause of fatal farm injuries to persons less than 20 years, by state, 1982-1996

Figure 9. Age group with the highest frequency of fatal farm injuries to persons less than 20 years, by state, 1982-1996 



\title{
Acknowledgments
}

The authors would like to thank the following people for their contributions in the development of this monograph:

\author{
Technical review \\ Lois A. Fingerhut, MA \\ Barbara C. Lee, RN, PhD \\ Mark A. Purschwitz, PhD \\ Frederick P. Rivara, MD, MPH \\ Anna E. Waller, ScD
}

Document Layout and Preparation

Joyce R. Spiker, DSR

Editorial review

Paul R. Keane, DSR

Cover Design

Herbert I. Linn, DSR 



\section{Public Health Summary}

\section{What are the hazards?}

According to data from the National Center for Health Statistics Mortality Data files, nearly 2,200 youth less than 20 years of age died of unintentional injuries (excluding transportation-related events) on farms in the United States between 1982 and 1996. Major causes of unintentional death on farms include farm machinery, drowning, and firearms. Together, these three causes accounted for $73 \%$ of the fatalities reported.

\section{How can youth be exposed or put at risk?}

Exposure to farm hazards is not limited to youth who are employed on farms. Youth can be fatally injured during work activities, while living on farms, while visiting farms, or when they accompany their working parents or adults into the fields. These various exposure sources make the farm a unique location for directing prevention strategies.

\section{What recommendations has the federal government made to protect youth's health?}

The Fair Labor Standards Act of 1938 (FLSA) and its amendments set standards for child labor in agriculture. However, FLSA covers only employees whose work involves production of agricultural goods which will leave the state through interstate commerce. While the FLSA specifically prohibits certain types of dangerous work (termed Hazardous Orders) by youth, these regulations do not apply to minors who are employed by their parents or a guardian on a farm owned or operated by their parent or a guardian.

Data that can be used to target injury prevention efforts are accumulating. NIOSH and other federal agencies encourage the use of these data to develop targeted prevention strategies. Additionally, NIOSH is conducting evaluations of prevention strategies to ensure that resources are applied effectively.

\section{Where can more information be found?}

New research efforts addressing childhood agricultural and farm injuries are underway at NIOSH and other organizations, and this information will be disseminated as soon as it becomes available. Additional information can be obtained through the NIOSH toll-free number or Website:

1-800-35-NIOSH

(800-356-4674)

www.cdc.gov/niosh 


\title{
Fatal Unintentional Farm Injuries Among Persons Less Than 20 Years of Age in the United States:
}

\author{
Geographic Profiles
}

\section{Introduction}

Each year on farms in the United States, an alarming number of youth less than 20 years of age are killed, injured, or permanently disabled. Children's involvement on farms is unique because youth not only actively work from an early age, but live and play on farms. Children are exposed to safety hazards from farm machinery, livestock, agricultural chemicals, structures, and bodies of water. Electrical hazards and firearms may also be present on farms.

Twenty-seven percent of the 4.6 million farm residents in the United States are youth less than 20 years old. ${ }^{1}$ Farm residents make up the largest population of youth exposed to farm safety hazards. However, relatives and friends of farm families, hired farm workers, or migrant workers may also be present on farms and exposed to similar hazards. Youth may also be involved in recreational activities on farms that expose them to safety hazards. Although the exact number of youth exposed to farm hazards annually is unknown, it has been estimated at more than two million. ${ }^{2}$

National data on fatal farm injuries occurring to youth and adolescents in the United States are limited. Data from the National Center for Health Statistics (NCHS) indicate that from 1979 through 1981, an average of 300 youth died on farms annually. Farm machines caused one-third of these deaths among youth less than 20 years old, and were responsible for half the deaths among youth under 10 years of age. ${ }^{3}$ A similar analysis for the years 1991 through 1993 demonstrates that fatal injuries on farms were reduced to 104 deaths annually, but the substantial contribution of farm machinery to these deaths did not change. Drowning incidents accounted for one-fourth of the total deaths, and one-third of the deaths among youth less than 5 years old. ${ }^{4}$

Few state-specific studies of fatal farm injuries of youth have been conducted. ${ }^{5-10}$ To prevent fatal farm injuries of youth in the United States, it is important to identify the leading causes of fatal injuries at the national level to guide broad-based prevention efforts. In addition, identifying the major causes of death at the regional and state level will guide efforts by state and community groups to address specific problems in their areas. Throughout the United States, geographic differences exist in agricultural populations, practices, and production. Additionally, exposure patterns differ among states, and also vary among population groups within the states. To date, regional and state-level data on childhood farm injuries in the United States have not been published. By addressing this gap, the data in this report may help policy makers, safety advocates, and the general public become more aware of major childhood farm safety issues in their states and regions, and may be useful to stakeholders as they develop prevention strategies specific to their needs. 



\section{Methodology}

This document is a summary of fatal farm injuries to persons less than 20 years of age as reported in the National Center for Health Statistics (NCHS) Mortality Data from 1982 through 1996. ${ }^{11}$ Fatal farm injuries are defined in this report as those which occurred on farms, regardless of production agriculture involvement. These injuries include those sustained during chores, paid work, or recreational activities such as hunting and swimming.

The NCHS Mortality Data were compiled from state death certificates filed from the Vital Statistics Offices in the United States. The edited data files included decedent demographics, geographic data, and information on the cause and physical location of death. Deaths to youth less than 20 years of age that occurred at a farm location were selected. NCHS data were coded according to the International Classification of Diseases codes (ICD-9) ${ }^{12}$ for location and underlying external cause of death. ICD-9 codes ranging from E850 through E869 and E880 through E928 were the only E codes recorded in the data files. Intentional deaths (E950-E969) and transportation events (E800E848) could not be identified in the data files because the ICD-9 guidelines excluded location of death for these events (cases were not coded, regardless of the location of death). However, because tractors are considered machinery, tractor-related deaths that occurred on the farm were included in this study. Events that occurred in the farm house or home premises of the farm were not identified as farm fatalities in the NCHS data files because the ICD-9 guidelines require they be classified as occurring at home. In addition, any fatalities that may have been misclassified in the original source document were excluded. Therefore, the number of farm fatalities reported in this document is considered conservative. The NCHS data do not distinguish between work and nonwork-related deaths, but include all fatalities on farms.

The Bureau of Census categorizes the nation into Census regions and Census divisions. NCHS data files follow this format. Specifically, there are four Census regions: West Region, Midwest Region, South Region, and the Northeast Region. Within the Census regions there are nine Census divisions: New England, Middle Atlantic, South Atlantic, East North Central, West North Central, East South Central, West South Central, Mountain, and Pacific. For the United States and Census regions, data are displayed in shade maps, tables, and figures by gender, age group, and cause of death. Additional tables summarize data for states and Census divisions. Individual cause-of-death profiles are provided, over the 15-year period, for states with at least ten deaths.

Lack of adequate state data on the number of youth exposed to farm hazards precludes assessment of risk and state-by-state comparisons. Therefore, the number of farm fatalities in this document for individual states should not be construed as a measure of risk.

\section{Interpretation of Data}

Caution should be exercised in interpreting the data presented in this document. The striking decreases in the frequency of farm fatalities among youth may be attributed to multiple factors, and do not necessarily reflect a similar reduction in risk. Changes in farm resident population, as well as improvements in equipment design, medical care, and educational programs may all have contributed to the decline in fatalities. 
The farm-resident population has decreased steadily over the years, according to Bureau of Census reports (the farm resident population estimates were last published in 1991). According to these reports, between 1982 and 1991, the youth farm resident population decreased by 28\%, for an average decrease of about 4\% per year. ${ }^{1,13-21}$ Statistics published by the United States Department of Agriculture (USDA) also indicated a decline in the number of farms and farm residents. ${ }^{22}$ Because the farm population has decreased, it is possible that smaller numbers of youth are exposed to farm hazards.

In addition to reductions in farm population, there has been an improvement in emergency medical and trauma care in rural areas. ${ }^{4}$ The use of safer farm machinery (e.g., tractors and other machines with rollover protective structures (ROPS) installed) has increased. ${ }^{4,23}$ Educational campaigns directed at farming communities, such as the Farm Safety Day Camps, FFA, and the 4-H programs, have been well received ${ }^{23}$ and more farm youth may be participating in farm machinery safety classes. $^{23}$ 


\section{Data Summary}

- Between 1982 and 1996, there were 2,174 farm deaths among youth less than 20 years of age.

- During 1982-1989, there were an average 181 deaths to youth on farms annually, decreasing to an average 103 deaths between 1990-1996. The average annual number of deaths decreased $43 \%$ between 1982-1989 and 1990-1996.

- About one out of every three farm deaths among youth occurred between the ages of 15 and 19 .

- Males accounted for $85.2 \%$ of the fatal farm injuries to youth less than 20 years of age.

- Females accounted for more than $20 \%$ of deaths in the age groups $0-4$ years and 5-9 years.

- Nearly $40 \%$ of the deaths among males were between the ages of 15 and 19 , while nearly $40 \%$ of the deaths among females occurred before age 5 .

- Farm machinery (including tractors), drowning, and firearm-related deaths represented $73 \%$ of fatal farm injuries to youth.

- Farm machinery-related deaths were the leading cause of death, accounting for $36 \%$ of deaths to youth less than 20 . Thirty percent of farm machinery-related deaths were among children less than 5 years of age. Machinery was the leading cause of farm deaths in 29 states.

- The average annual number of farm machinery-related deaths decreased $60 \%$ between $1982-$ 1989 and 1990-1996 among youth 15-19 years of age. The smallest decrease (33\%) was among youth 5-9 years of age.

- Drowning was the second leading cause of death on farms (27\%), with children less than 5 years of age accounting for $32 \%$ of the deaths. Drowning was the leading cause of farm deaths in 17 states.

- Between 1982-1989 and 1990-1996, the greatest decrease in the average annual number of drowning-related farm fatalities (64\%) was among youth $10-14$ years of age.

- Firearms accounted for $11 \%$ of the fatal farm injuries, with slightly more than half of the firearms deaths reported among youth 15-19 years of age (58\%). Firearms were the leading cause of death in two states (Alabama and Wyoming).

- Between 1982-1989 and 1990-1996, the greatest decline in the average annual number of firearms-related farm fatalities (57\%) was seen in youth 10-14 years of age. The decrease noted among youth 15-19 years of age between these time periods was $36 \%$.

- For deaths attributed to machinery, drowning, and animals, the greatest numbers of deaths occurred among children under 5 years of age. The greatest numbers of deaths from mechanical suffocation occurred between ages 10 and 14, with firearms and electrocution deaths most common between ages 15 and 19 . 
- Two regions, the South Region and the Midwest Region, accounted for 79\% of the fatal farm injuries.

- The greatest proportions of deaths in the Northeast Region and the West Region were among youth 0-4 years. In the Midwest Region and the South Region, the greatest proportions were among youth 15-19 years.

- The average annual number of fatal farm injuries among youth declined across all regions between 1982-1989 and 1990-1996. Among the regions, overall levels of decline varied, and were also inconsistent across age groups.

- In general, regional declines in machinery-related deaths were greatest among youth 15-19 years of age, and smallest among youth 5-9 years of age.

- Texas reported the most fatal injuries (204 deaths), representing $9.4 \%$ of the total.

- Five states reported 100 or more deaths each (Iowa, Missouri, Pennsylvania, Texas, and Wisconsin).

- Twenty-two states reported 40 or more farm deaths to youth during this period (Arkansas, California, Colorado, Georgia, Idaho, Indiana, Illinois, Iowa, Kansas, Kentucky, Missouri, Minnesota, Mississippi, Michigan, North Carolina, Ohio, Oklahoma, Pennsylvania, South Dakota, Tennessee, Texas, and Wisconsin). 


\section{Prevention of Childhood Farm Fatalities}

In recent years, significant progress has been made in reducing farm injuries and fatalities. ${ }^{4,23}$ Progress has been attributed to more widespread use of ROPS, improved emergency care in rural areas, certification of youth 14-15 years of age in the operation of farm machinery, and general educational efforts geared toward farm safety. However, despite progress made in recent years, the toll of farm fatalities among youth remains high. Further, as this document demonstrates, declines have not been uniformly strong in all geographic areas or age groups, or for all causes of death.

Strategies that have been suggested for prevention of childhood farm fatalities have several recurring themes: the importance of separating children from injury hazards; the need for adult supervision; and the need for adults present to take responsibility for assessing safety risks to children and youth and eliminating hazards. In general, prevention programs for specific types of injuries take each of these dimensions into account.

For example, strategies recommended for preventing deaths associated with farm machinery include providing enclosed play spaces for young children away from work areas; checking a work area for the presence and location of children before starting to operate any machinery; evaluating youth's maturity, knowledge, and physical abilities to operate machinery before assigning a chore or work task; and ensuring that youth adhere to standard safety practices such as using seat belts on ROPSequipped tractors. ${ }^{9-10}$ Elements of a drowning prevention program may include erecting barriers to separate children from ponds or other drowning hazards; supervising children at all times when they are near a body of water; and permitting youth to swim only when another person is present. ${ }^{24} \mathrm{~A}$ variety of agencies and organizations, including those listed in the section entitled "Additional Resources" on page 11, can provide further information about prevention of childhood injuries and fatalities on farms.

While numerous promising prevention strategies have been developed and implemented, few have been formally evaluated to date. NIOSH is actively pursuing such evaluations through its Childhood Agricultural Injury Prevention Initiative. Results of these rigorous evaluations will be invaluable in developing future interventions. However, at present, there is a critical need to use existing information to guide prevention efforts focused on farm fatalities among children and youth. 



\section{References}

1. Dacquel LT, Dahmann DC [1993]. Residents of farms and rural areas: 1991. Washington, DC: US Government Printing Office, Bureau of the Census, Current Population Reports, Series P-20, No. 472.

2. National Committee for Childhood Agricultural Injury Prevention [1996]. Children and agriculture: opportunities for safety and health: a national action plan, Marshfield, WI: Marshfield Clinic.

3. Rivara FP [1985]. Fatal and nonfatal farm injuries to children and adolescents in the United States. Pediatrics 76:567-573.

4. Rivara FP [1997]. Fatal and non-fatal farm injuries to children and adolescents in the United States 1990-3. Injury Prevention 3:190-194.

5. Tormoehlen R [1986]. Fatal farm accidents occurring to Wisconsin children, 1970-1984. Presented at the 1986 American Society of Agricultural Engineers, Chicago, IL. Paper No. 86-5514.

6. Salmi LR, Weiss HB, Peterson PL, Spengler RF, Sattin RW, Anderson HA [1989]. Fatal farm injuries among young children. Pediatrics 83:267-271.

7. Stallones L [1989]. Fatal unintentional injuries among Kentucky farm children: 1979 to 1985. Journal of Rural Health 5:246-256.

8. Schenker MB, Lopez R, Wintemute G [1995]. Farm-related fatalities among children in California. Am J Public Health 85:89-92.

9. CDC [1999]. Childhood work-related agricultural fatalities-Minnesota, 1994-1997. MMWR 48:332-335.

10. CDC [1999]. Deaths among children aged less than 5 years from farm machinery runoverIowa, Kentucky, and Wisconsin, 1995-1998, and United States, 1990-1995. MMWR 48:605-608.

11. CDC, National Center for Health Statistics. Multiple Cause of Death Public Use Data, 1982-1996.

12. World Health Organization [1977]. International classification of diseases: manual on the international statistical classification of diseases, injuries, and cause of death. $9^{\text {th }}$ revision. Geneva, Switzerland.

13. Banks VJ, Mills KM [1983]. Farm Population of the United States: 1982. Washington, DC: U.S. Government Printing Office, Bureau of the Census, Current Population Reports, Series P-27, No. 56. 
14. Banks VJ, Mills KM [1984]. Farm Population of the United States: 1983. Washington, DC: U.S. Government Printing Office, Bureau of the Census, Current Population Reports, Series P-27, No. 57.

15. Bureau of the Census [1985]. Farm Population of the United States: 1984. Washington, DC: U.S. Government Printing Office, Bureau of the Census, Current Population Reports, Series P-27, No. 58.

16. Bureau of the Census [1986]. Farm Population of the United States: 1985. Washington, DC: U.S. Government Printing Office, Bureau of the Census, Current Population Reports, Series P-27, No. 59.

17. Bureau of the Census [1987]. Farm Population of the United States: 1986. Washington, DC: U.S. Government Printing Office, Bureau of the Census, Current Population Reports, Series P-27, No. 60.

18. Bureau of the Census [1988]. Rural and Rural Farm Population: 1987. Washington, DC: U.S. Government Printing Office, Bureau of the Census, Current Population Reports, Series P-27, No. 61.

19. Bureau of the Census [1989]. Rural and Rural Farm Population: 1988. Washington, DC: U.S. Government Printing Office, Bureau of the Census, Current Population Reports, Series P-20, No. 439.

20. LeClere F, Dahmann DC [1990]. Residents of farms and rural areas: 1989. Washington, DC: U.S. Government Printing Office, Bureau of the Census, Current Population Reports, Series P-20, No. 446.

21. Dahmann DC, Dacquel LT [1992]. Residents of farms and rural areas: 1990. Washington, DC: U.S. Government Printing Office, Bureau of the Census, Current Population Reports, Series P-20, No. 457.

22. U.S. Department of Agriculture [1994]. Agriculture Fact Book, 1994. U.S. Government Printing Office.

23. Myers JR, Hard DL [1995]. Work-related fatalities in the agricultural production and services sectors, 1980-1989. Am J Ind Med 27:51-63.

24. National Children's Center for Rural and Agricultural Health and Safety [2000]. Drowning Prevention Strategies: What Can Child Safety Advocates Do? (Website). www.marshfieldclinic.org/research/children/resources/drowning/strategies.html. Last accessed June 1, 2001. 


\section{Additional Resources}

NOTE: The addresses below were correct as of June, 2001. Since Internet addresses for Web sites change frequently, readers are cautioned that slight changes may have taken place since that time.

Centers for Agricultural Disease and Injury Research, Education and Prevention National Institute for Occupational Safety and Health

Phone: (304) 285-5749

www.cdc.gov/niosh/agctrhom.html

Farm Safety Program

Cooperative State Research Education and Extension Service

U.S. Department of Agriculture

Phone: (202) 401-0151

www.reeusda.gov/pas/AGSYS/FARMSAFE/Farmsafe.htm

Employment Standards Administration, Wage and Hour Division

U.S. Department of Labor

Phone: (866) 487-9243

www.dol.gov/dol/esa

Farm Safety 4 Just Kids

Phone: (800) 423-5437 or (515) 758-2827

www.fs4jk.org

National Center for Injury Prevention and Control

Phone: (770) 488-1506

www.cdc.gov/ncipc/ncipchm.htm

National Children's Center for Rural and Agricultural Health and Safety

Phone: (888) 924-SAFE (7233)

www.marshfieldclinic.org/research/children

National FFA Organization

Phone: (317) 802-6060

www.ffa.org

National Institute for Occupational Safety and Health

Phone: (800) 356-7674

www.cdc.gov/niosh

National SAFE KIDS Campaign

www.safekids.org 
National Safety Council, Agriculture Division

www.nsc.org/mem/agri.htm

North American Guidelines for Children's Agricultural Tasks (NAGCAT)

Phone: (888) 924-SAFE (7233)

www.nagcat.org 
Table 1. Fatal farm injuries to persons less than 20 years, by year and age group, United States, 1982-1996

\begin{tabular}{|c|c|c|c|c|c|}
\hline Year & 0 - 4 years & $\mathbf{5}-\mathbf{9}$ years & $\mathbf{1 0}-\mathbf{1 4}$ years & $\mathbf{1 5}-\mathbf{1 9}$ years & Total \\
\hline \hline 1982 & 45 & 31 & 47 & 70 & 193 \\
\hline 1983 & 51 & 38 & 65 & 97 & 251 \\
\hline 1984 & 41 & 34 & 58 & 77 & 210 \\
\hline 1985 & 59 & 38 & 37 & 76 & 210 \\
\hline 1986 & 50 & 28 & 38 & 47 & 163 \\
\hline 1987 & 40 & 30 & 36 & 46 & 152 \\
\hline 1988 & 31 & 25 & 28 & 55 & 139 \\
\hline 1989 & 30 & 35 & 26 & 41 & 132 \\
\hline 1990 & 36 & 36 & 27 & 42 & 141 \\
\hline 1991 & 29 & 25 & 21 & 29 & 104 \\
\hline 1992 & 20 & 25 & 22 & 39 & 106 \\
\hline 1993 & 29 & 13 & 26 & 33 & 101 \\
\hline 1994 & 26 & 23 & 18 & 30 & 97 \\
\hline 1995 & 20 & 17 & 16 & 28 & 81 \\
\hline 1996 & 20 & 23 & 19 & 32 & 94 \\
\hline Total & 527 & 421 & 484 & 742 & 2174 \\
\hline
\end{tabular}

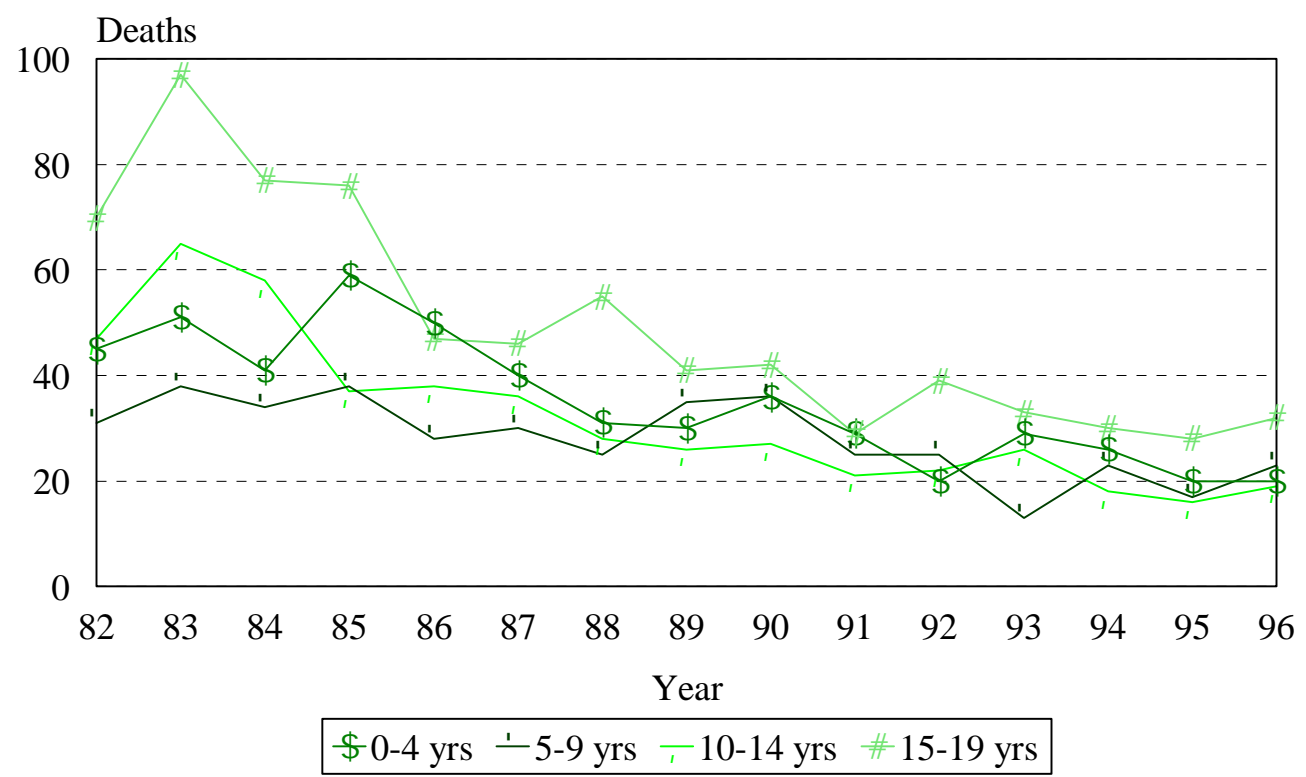

Figure 1. Trend of fatal farm injuries to persons less than 20 years, by age group, United States, 1982-1996 (N=2174) 
Table 2. Fatal farm injuries to persons less than 20 years, by gender and age group, United States, 1982-1996

\begin{tabular}{|l|c|c|c|}
\hline Age Group & Male & Female & Total \\
\hline \hline 0-4 years & 404 & 123 & 527 \\
\hline 5-9 years & 327 & 94 & 421 \\
\hline 10-14 years & 427 & 57 & 484 \\
\hline 15-19 years & 695 & 47 & 742 \\
\hline Total & 1853 & 321 & 2174 \\
\hline
\end{tabular}

Table 3. Percentage change in average annual number of fatal farm injuries to persons less than 20 years, by age group, United States, 1982-1989 and 1990-1996

\begin{tabular}{|l|c|c|c|c|c|}
\hline All Causes of Death & $\mathbf{0}-\mathbf{4}$ years & $\mathbf{5}-\mathbf{9}$ years & $\mathbf{1 0}-\mathbf{1 4}$ years & $\mathbf{1 5} \mathbf{- 1 9}$ years & Total \\
\hline \hline $1982-1989$ & 43 & 32 & 42 & 64 & 181 \\
\hline $1990-1996$ & 26 & 23 & 21 & 33 & 103 \\
\hline \% change & -40 & -28 & -50 & -48 & -43 \\
\hline
\end{tabular}

Table 4. Causes of fatal farm injuries to persons less than 20 years, United States, 1982-1996

\begin{tabular}{|l|c|c|}
\hline \multicolumn{1}{|c|}{ Cause of Death } & Number & Percent \\
\hline \hline Machinery (E919) & 773 & 35.6 \\
\hline Drowning (E910) & 585 & 26.9 \\
\hline Firearms (E922) & 237 & 10.9 \\
\hline Struck by or against/caught in or between objects (E916-E918) & 109 & 5.0 \\
\hline Mechanical suffocation (E911-E913) & 107 & 4.9 \\
\hline Injury caused by animals (E905-E906) & 82 & 3.7 \\
\hline Electric current (E925) & 78 & 3.6 \\
\hline Falls (E880-E888) & 69 & 3.2 \\
\hline Nature/environment (E900-E904, E907-E909) & 43 & 2.0 \\
\hline Accidental poisoning (E850-E869) & 23 & 1.1 \\
\hline Fire \& flames (E890-E899) & 22 & 1.0 \\
\hline All other causes (E920, E921, E923, E924, E928) & 46 & 2.1 \\
\hline All causes of death (E850-E869 and E880-E928) & 2174 & 100.0 \\
\hline
\end{tabular}




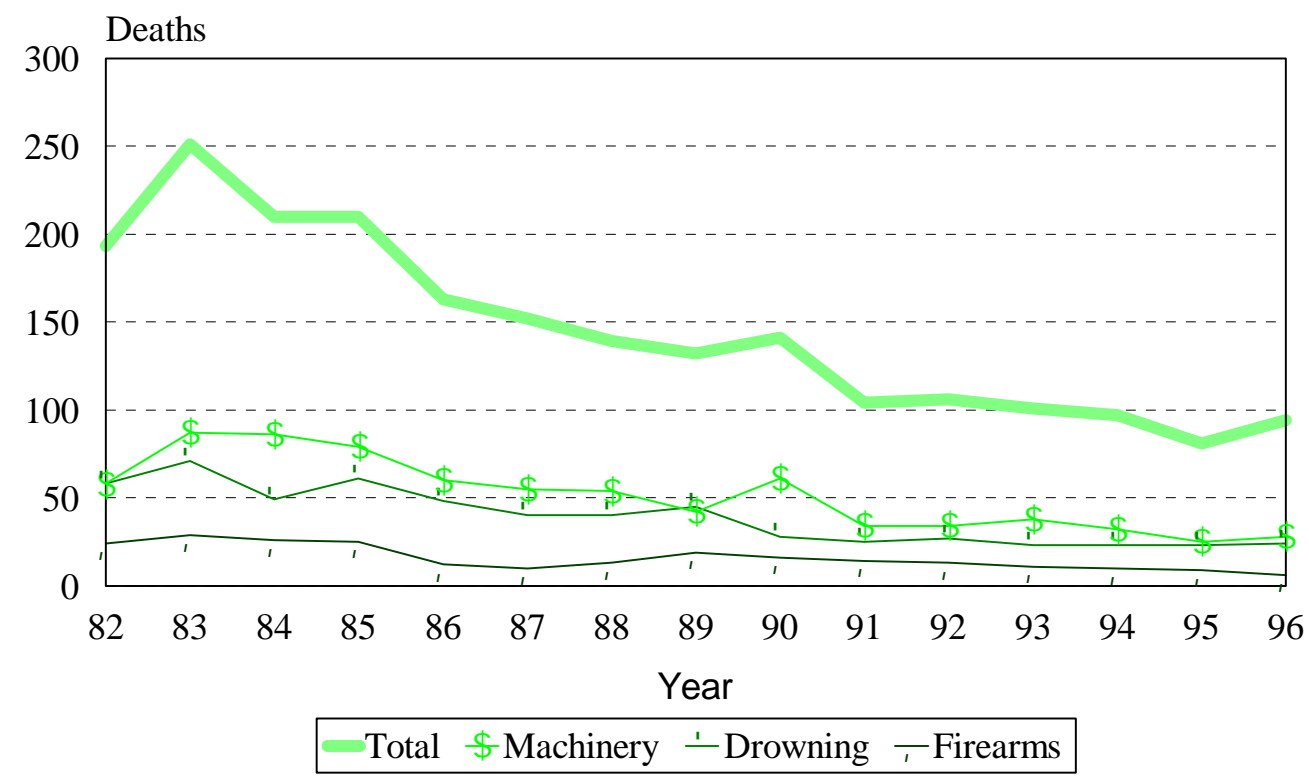

Figure 2. Trend of the leading causes of fatal farm injuries to persons less than 20 years, United States, 1982-1996

Table 5. Causes of fatal farm injuries to persons less than 20 years, by gender, United States, 1982-1996

\begin{tabular}{|l|r|r|c|}
\hline \multicolumn{1}{|c|}{ Cause of Death } & Male & Female & Total \\
\hline \hline Machinery (E919) & 658 & 115 & 773 \\
\hline Drowning (E910) & 500 & 85 & 585 \\
\hline Firearms (E922) & 226 & 11 & 237 \\
\hline Struck by or against/caught in or between objects (E916-E918) & 91 & 18 & 109 \\
\hline Mechanical suffocation (E911-E913) & 100 & 7 & 107 \\
\hline Injury caused by animals (E905-E906) & 50 & 32 & 82 \\
\hline Electric current (E925) & 69 & 9 & 78 \\
\hline Falls (E880-E888) & 55 & 14 & 69 \\
\hline Nature/environment (E900-E904, E907-E909) & 31 & 12 & 43 \\
\hline Accidental poisoning (E850-E869) & 17 & 6 & 23 \\
\hline Fire \& flames (E890-E899) & 16 & 6 & 22 \\
\hline All other causes (E920,E921,E923,E924,E928) & 40 & 6 & 46 \\
\hline All causes of death (E850-E869 and E880-E928) & 1853 & 321 & 2174 \\
\hline
\end{tabular}


Table 6. Causes of fatal farm injuries to persons less than 20 years, by age group, United States, 1982-1996

\begin{tabular}{|l|r|r|r|c|c|}
\hline \multicolumn{1}{|c|}{ Cause of Death } & $\begin{array}{c}\mathbf{0 - 4} \\
\text { years }\end{array}$ & $\begin{array}{c}\mathbf{5} \text { - 9 } \\
\text { years }\end{array}$ & $\begin{array}{c}\mathbf{1 0} \text { - 14 } \\
\text { years }\end{array}$ & $\begin{array}{c}\mathbf{1 5} \text { - 19 } \\
\text { years }\end{array}$ & Total \\
\hline \hline Machinery (E919) & 229 & 188 & 141 & 215 & 773 \\
\hline Drowning (E910) & 186 & 108 & 118 & 173 & 585 \\
\hline Firearms (E922) & 9 & 15 & 76 & 137 & 237 \\
\hline $\begin{array}{l}\text { Struck by or against/caught in or } \\
\text { between objects (E916-E918) }\end{array}$ & 30 & 29 & 22 & 28 & 109 \\
\hline Mechanical suffocation (E911-E913) & 11 & 20 & 49 & 27 & 107 \\
\hline Injury caused by animals (E905-E906) & 29 & 22 & 19 & 12 & 82 \\
\hline Electric current (E925) & 4 & 4 & 20 & 50 & 78 \\
\hline Falls (E880-E888) & 12 & 17 & 16 & 24 & 69 \\
\hline $\begin{array}{l}\text { Nature/environment (E900-E904, } \\
\text { E907-E909) }\end{array}$ & 5 & 2 & 6 & 30 & 43 \\
\hline Accidental poisoning (E850-E869) & 2 & 0 & 4 & 17 & 23 \\
\hline Fire \& flames (E890-E899) & 3 & 7 & 4 & 8 & 22 \\
\hline $\begin{array}{l}\text { All other causes (E920, E921, E923, } \\
\text { E924, E928) }\end{array}$ & 7 & 9 & 9 & 21 & 46 \\
\hline $\begin{array}{l}\text { All causes of death (E850-E869 and } \\
\text { E880-E928) }\end{array}$ & 527 & 421 & 484 & 742 & 2174 \\
\hline
\end{tabular}


Table 7. Causes of fatal farm injuries to males less than 20 years, by age group, United States, 1982-1996

\begin{tabular}{|l|c|c|c|c|c|}
\hline \multicolumn{1}{|c|}{ Cause of Death } & $\begin{array}{c}\mathbf{0}-\mathbf{4} \\
\text { years }\end{array}$ & $\begin{array}{c}\mathbf{5}-\mathbf{9} \\
\text { years }\end{array}$ & $\begin{array}{c}\mathbf{1 0}-\mathbf{1 4} \\
\text { years }\end{array}$ & $\begin{array}{c}\mathbf{1 5} \text { - 19 } \\
\text { years }\end{array}$ & Total \\
\hline \hline Machinery (E919) & 174 & 154 & 125 & 205 & 658 \\
\hline Drowning (E910) & 149 & 82 & 101 & 168 & 500 \\
\hline Firearms (E922) & 8 & 12 & 74 & 132 & 226 \\
\hline Mechanical suffocation (E911-E913) & 10 & 16 & 47 & 27 & 100 \\
\hline $\begin{array}{l}\text { Struck by or against/caught in or } \\
\text { between objects (E916-E918) }\end{array}$ & 23 & 21 & 19 & 28 & 91 \\
\hline Electric current (E925) & 3 & 3 & 19 & 44 & 69 \\
\hline Falls (E880-E888) & 9 & 12 & 14 & 20 & 55 \\
\hline Injury caused by animals (E905-E906) & 17 & 14 & 9 & 10 & 50 \\
\hline $\begin{array}{l}\text { Nature/environment (E900-E904, } \\
\text { E907-E909) }\end{array}$ & 1 & 1 & 5 & 24 & 31 \\
\hline Accidental poisoning (E850-E869) & 2 & 0 & 4 & 11 & 17 \\
\hline Fire \& flames (E890-E899) & 2 & 5 & 2 & 7 & 16 \\
\hline $\begin{array}{l}\text { All other causes (E920, E921, E923, } \\
\text { E924, E928) }\end{array}$ & 6 & 7 & 8 & 19 & 40 \\
\hline $\begin{array}{l}\text { All causes of death (E850-E869 and } \\
\text { E880-E928) }\end{array}$ & 404 & 327 & 427 & 695 & 1853 \\
\hline
\end{tabular}


Table 8. Causes of fatal farm injuries to females less than 20 years, by age group, United States, 1982-1996

\begin{tabular}{|l|c|c|c|c|c|}
\hline \multicolumn{1}{|c|}{ Cause of Death } & $\begin{array}{c}\mathbf{0}-\mathbf{4} \\
\text { years }\end{array}$ & $\begin{array}{c}\mathbf{5 - 9} \\
\text { years }\end{array}$ & $\begin{array}{c}\mathbf{1 0}-\mathbf{1 4} \\
\text { years }\end{array}$ & $\begin{array}{c}\mathbf{1 5} \text { - 19 } \\
\text { years }\end{array}$ & Total \\
\hline \hline Machinery (E919) & 55 & 34 & 16 & 10 & 115 \\
\hline Drowning (E910) & 37 & 26 & 17 & 5 & 85 \\
\hline Injury caused by animals (E905-E906) & 12 & 8 & 10 & 2 & 32 \\
\hline $\begin{array}{l}\text { Struck by or against/caught in or } \\
\text { between objects (E916-E918) }\end{array}$ & 7 & 8 & 3 & 0 & 18 \\
\hline Falls (E880-E888) & 3 & 5 & 2 & 4 & 14 \\
\hline $\begin{array}{l}\text { Nature/environment (E900-E904, } \\
\text { E907-E909) }\end{array}$ & 4 & 1 & 1 & 6 & 12 \\
\hline Firearms (E922) & 1 & 3 & 2 & 5 & 11 \\
\hline Electric current (E925) & 1 & 1 & 1 & 6 & 9 \\
\hline Mechanical suffocation (E911-E913) & 1 & 4 & 2 & 0 & 7 \\
\hline Accidental poisoning (E850-E869) & 0 & 0 & 0 & 6 & 6 \\
\hline Fire \& flames (E890-E899) & 1 & 2 & 2 & 1 & 6 \\
\hline $\begin{array}{l}\text { All other causes (E920, E921, E923, } \\
\text { E924, E928) }\end{array}$ & 1 & 2 & 1 & 2 & 6 \\
\hline $\begin{array}{l}\text { All causes of death (E850-E869 and } \\
\text { E880-E928) }\end{array}$ & & 94 & 57 & 47 & 321 \\
\hline
\end{tabular}


Table 9. Percentage change in average annual number of fatal farm injuries to persons less than 20 years due to machinery, drowning, and firearms, by age group, United States, 1982-1989 and 1990-1996

\begin{tabular}{|c|c|c|c|c|c|}
\hline Cause of D eath & 0 - 4 years & 5 - 9 years & 10 - 14 years & 15 -19 years & Total \\
\hline \multicolumn{6}{|l|}{ M achinery: } \\
\hline 1982-1989 & 19 & 15 & 12 & 20 & 65 \\
\hline 1990-1996 & 11 & 10 & 7 & 8 & 36 \\
\hline$\%$ change & -42 & -33 & -42 & -60 & -45 \\
\hline \multicolumn{6}{|l|}{ D rowning: } \\
\hline 1982-1989 & 16 & 9 & 11 & 15 & 52 \\
\hline 1990-1996 & 8 & 5 & 4 & 8 & 25 \\
\hline$\%$ change & -50 & -44 & -64 & -47 & -52 \\
\hline \multicolumn{6}{|l|}{ F irearms: } \\
\hline 1982-1989 & $<1$ & 1 & 7 & 11 & 20 \\
\hline 1990-1996 & $<1$ & $<1$ & 3 & 7 & 11 \\
\hline$\%$ change & -- & -- & -57 & -36 & -45 \\
\hline
\end{tabular}

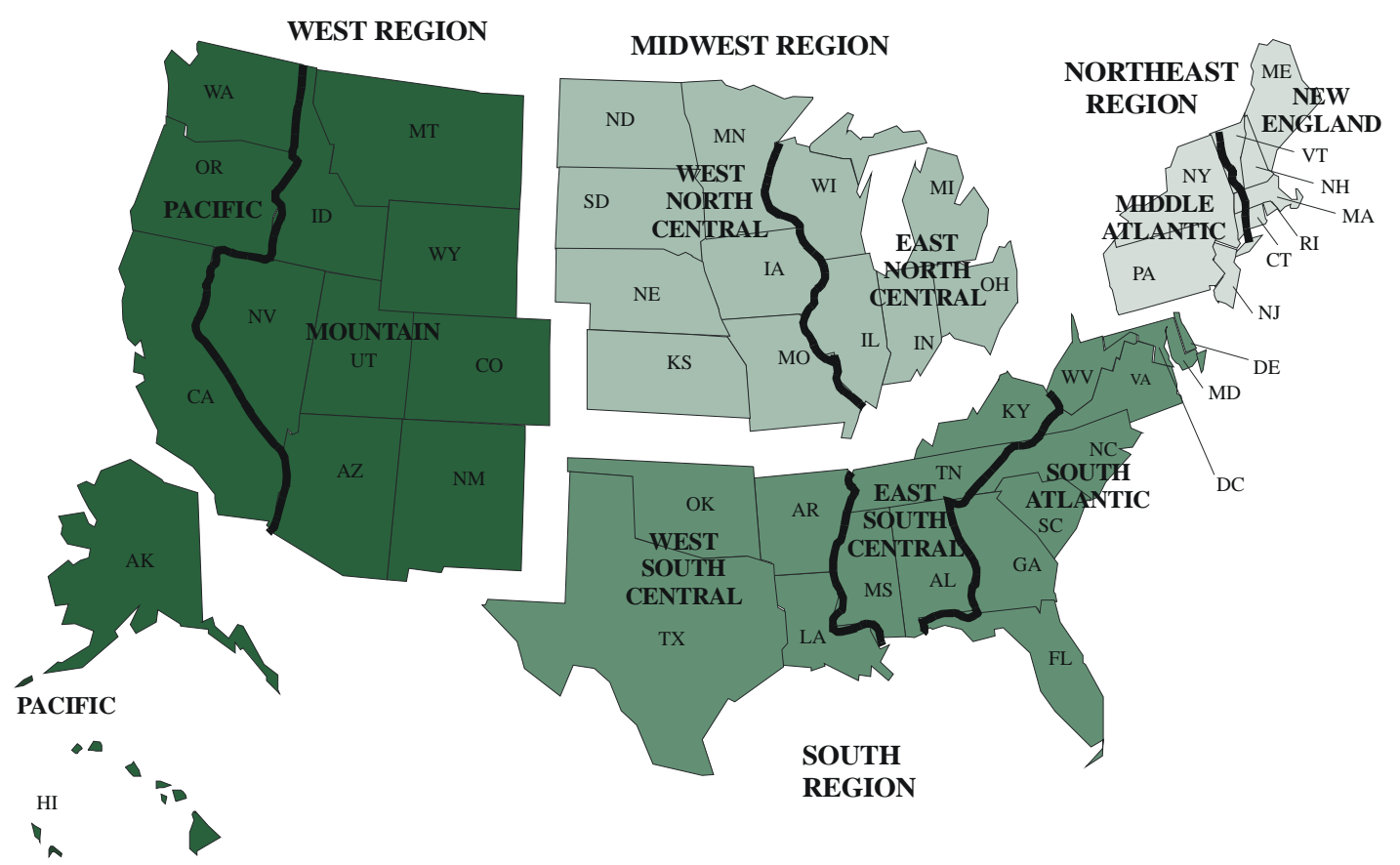

Figure 3. Map of the United States showing Census regions, Census divisions, and states 
Table 10. Fatal farm injuries to persons less than 20 years, by Census region and age group, United States, 1982-1996

\begin{tabular}{|l|c|c|c|c|c|}
\hline Region & $\mathbf{0}-\mathbf{4}$ years & $\mathbf{5}-\mathbf{9}$ years & $\mathbf{1 0} \mathbf{- 1 4}$ years & $\mathbf{1 5} \mathbf{- 1 9}$ years & Total \\
\hline \hline Northeast & 58 & 30 & 41 & 50 & 179 \\
\hline Midwest & 228 & 178 & 168 & 270 & 844 \\
\hline South & 147 & 162 & 217 & 337 & 863 \\
\hline West & 94 & 51 & 58 & 85 & 288 \\
\hline Total & 527 & 421 & 484 & 742 & 2174 \\
\hline
\end{tabular}

Table 11. Percentage change in average annual number of fatal farm injuries to persons less than 20 years from all causes, by age group, Northeast Region, 1982-1989 and 1990-1996

\begin{tabular}{|c|c|c|c|c|c|}
\hline All Causes of Death & $\mathbf{0}-\mathbf{4}$ years & $\mathbf{5}$ - 9 years & $\mathbf{1 0}-\mathbf{1 4}$ years & $\mathbf{1 5}$-19 years & Total \\
\hline \hline $1982-1989$ & 4 & 2 & 3 & 4 & 14 \\
\hline $1990-1996$ & 4 & 2 & 2 & 2 & 10 \\
\hline$\%$ change & -- & -- & -33 & -50 & -29 \\
\hline
\end{tabular}

Table 12. Percentage change in average annual number of fatal farm injuries to persons less than 20 years due to machinery, by age group, Northeast Region, 1982-1989 and 1990-1996

\begin{tabular}{|l|c|c|c|c|c|}
\hline Cause of Death & $\mathbf{0}-\mathbf{4}$ years & $\mathbf{5}-\mathbf{9}$ years & $\mathbf{1 0} \mathbf{- 1 4}$ years & $\mathbf{1 5} \mathbf{- 1 9}$ years & Total \\
\hline \hline Machinery: & & & & & \\
\hline $1982-1989$ & 2 & 1 & 1 & 2 & 6 \\
\hline $1990-1996$ & 2 & 1 & 1 & $<1$ & 4 \\
\hline \% change & -- & -- & -- & -- & -33 \\
\hline
\end{tabular}




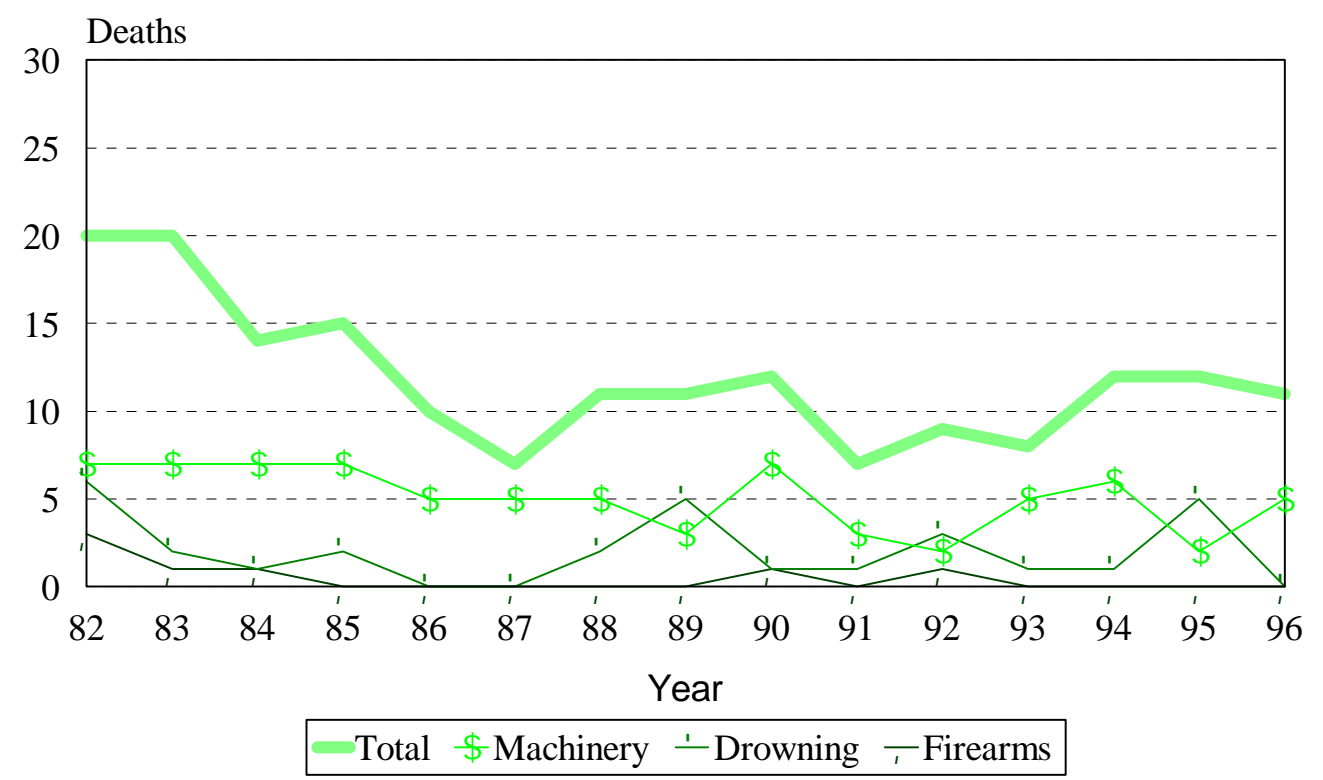

Figure 4. Trend of the leading causes of fatal farm injuries to persons less than 20 years, Northeast Region, 1982-1996 (N=179)

Table 13. Percentage change in average annual number of fatal farm injuries to persons less than 20 years from all causes, by age group, Midwest Region, 1982-1989 and 1990-1996

\begin{tabular}{|c|c|c|c|c|c|}
\hline All Causes of Death & $\mathbf{0}-\mathbf{4}$ years & $\mathbf{5}-\mathbf{9}$ years & $\mathbf{1 0}-\mathbf{1 4}$ years & $\mathbf{1 5}-\mathbf{1 9}$ years & Total \\
\hline \hline $1982-1989$ & 19 & 13 & 14 & 23 & 69 \\
\hline $1990-1996$ & 10 & 10 & 8 & 12 & 41 \\
\hline$\%$ change & -47 & -23 & -43 & -48 & -41 \\
\hline
\end{tabular}


Table 14. Percentage change in average annual number of fatal farm injuries to persons less than 20 years due to machinery and drowning, by age group, Midwest Region, 1982-1989 and 1990-1996

\begin{tabular}{|l|c|c|c|c|c|}
\hline Cause of Death & $\mathbf{0}$ - 4 years & $\mathbf{5 ~ - ~ 9 ~ y e a r s ~}$ & $\mathbf{1 0}$ - 14 years & $\mathbf{1 5}$-19 years & Total \\
\hline \hline Machinery: & & & & & \\
\hline $1982-1989$ & 11 & 8 & 5 & 6 & 30 \\
\hline 1990-1996 & 6 & 6 & 3 & 3 & 17 \\
\hline \% change & -45 & -25 & -40 & -50 & -43 \\
\hline \multicolumn{7}{|l|}{} \\
\hline Drowning: & \multicolumn{7}{|l|}{} & & & \\
\hline 1982-1989 & 5 & 2 & 2 & 4 & 13 \\
\hline 1990-1996 & 3 & 1 & $<1$ & 2 & 7 \\
\hline \% change & -40 & -50 & -- & -50 & -46 \\
\hline
\end{tabular}

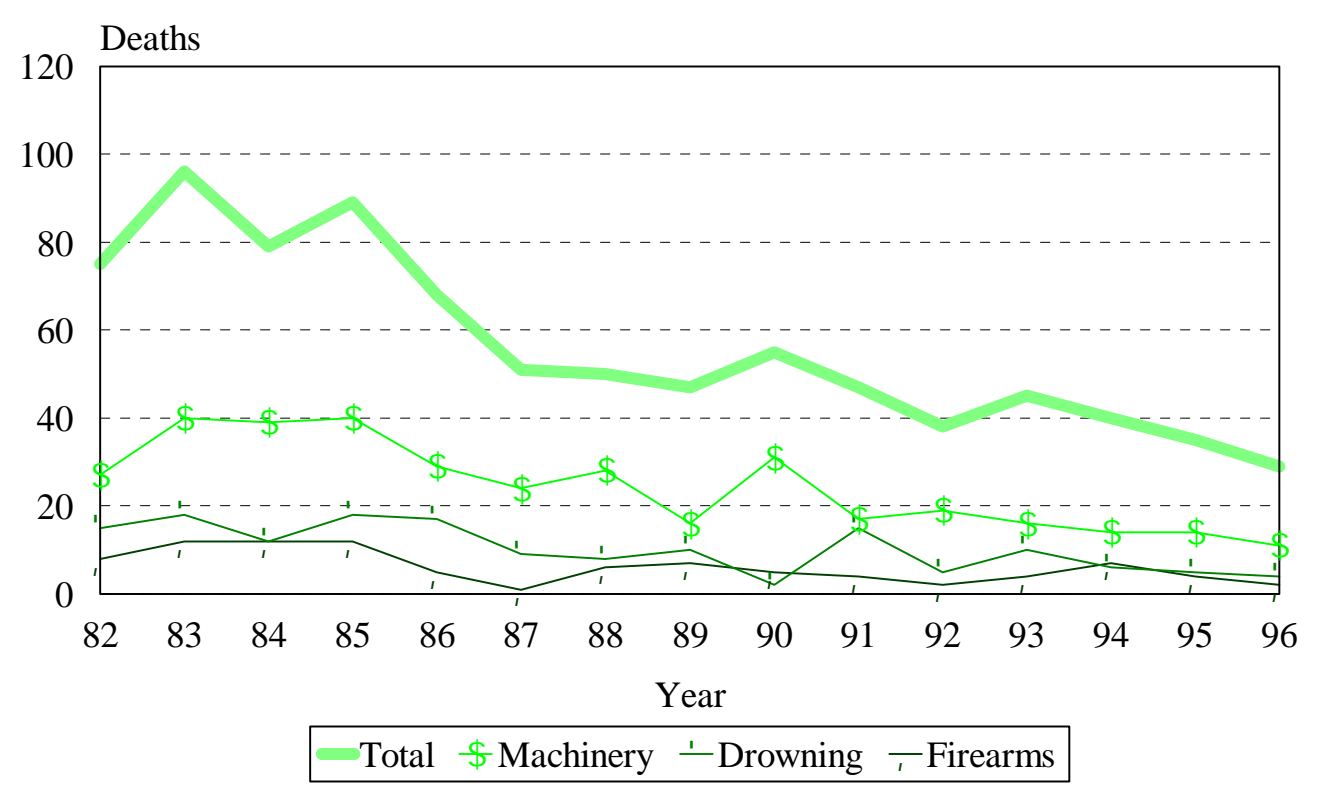

Figure 5. Trend of the leading causes of fatal farm injuries to persons less than 20 years, Midwest Region, 1982-1996 (N=864) 
Table 15. Percentage change in average annual number of fatal farm injuries to persons less than 20 years from all causes, by age group, South Region, 1982-1989 and 1990-1996

\begin{tabular}{|c|c|c|c|c|c|}
\hline All Causes of Death & $\mathbf{0}-\mathbf{4}$ years & $\mathbf{5}-\mathbf{9}$ years & $\mathbf{1 0} \mathbf{- 1 4}$ years & $\mathbf{1 5} \mathbf{- 1 9}$ years & Total \\
\hline \hline $1982-1989$ & 12 & 13 & 20 & 30 & 75 \\
\hline $1990-1996$ & 7 & 8 & 8 & 14 & 38 \\
\hline$\%$ change & -42 & -38 & -60 & -53 & -49 \\
\hline
\end{tabular}

Table 16. Percentage change in average annual number of fatal farm injuries to persons less than 20 years due to machinery and drowning, by age group, South Region, 1982-1989 and 1990-1996

\begin{tabular}{|l|c|c|c|c|c|}
\hline Cause of Death & $\mathbf{0}-\mathbf{4}$ years & $\mathbf{5}-\mathbf{9}$ years & $\mathbf{1 0}$ - 14 years & $\mathbf{1 5}$-19 years & Total \\
\hline \hline Machinery: & & & & & \\
\hline $1982-1989$ & 4 & 4 & 3 & 9 & 21 \\
\hline $1990-1996$ & 2 & 3 & 2 & 2 & 9 \\
\hline \% change & -50 & -25 & -50 & -78 & -57 \\
\hline \multicolumn{7}{|l|}{} & & & & \\
\hline Drowning: & 6 & 6 & 9 & 10 & 30 \\
\hline $1982-1989$ & 3 & 2 & 3 & 5 & 14 \\
\hline $1990-1996$ & -50 & -67 & -67 & -50 & -53 \\
\hline$\%$ change & & & & & \\
\hline
\end{tabular}

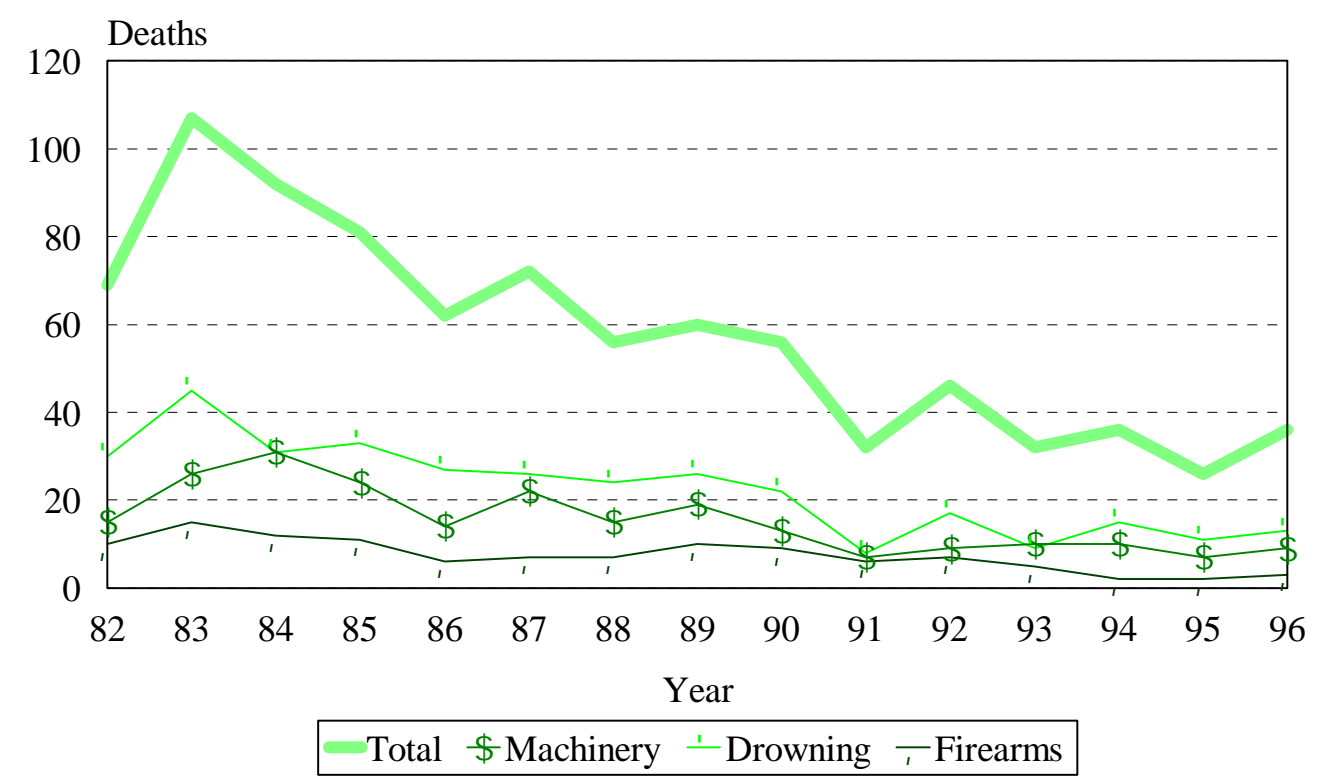

Figure 6. Trend of the leading causes of fatal farm injuries to persons less than 20 years, South Region, 1982-1996 (N=863) 
Table 17. Percentage change in average annual number of fatal farm injuries to persons less than 20 years from all causes, by age group, West Region, 1982-1989 and 1990-1996

\begin{tabular}{|c|c|c|c|c|c|}
\hline All Causes of Death & $\mathbf{0}-\mathbf{4}$ years & $\mathbf{5}-\mathbf{9}$ years & $\mathbf{1 0}-\mathbf{1 4}$ years & $\mathbf{1 5} \mathbf{- 1 9}$ years & Total \\
\hline \hline $1982-1989$ & 8 & 4 & 5 & 7 & 24 \\
\hline $1990-1996$ & 5 & 3 & 3 & 4 & 14 \\
\hline$\%$ change & -38 & -25 & -40 & -43 & -42 \\
\hline
\end{tabular}

Table 18. Percentage change in average annual number of fatal farm injuries to persons less than 20 years due to machinery, by age group, West Region, 1982-1989 and 1990-1996

\begin{tabular}{|l|c|c|c|c|c|}
\hline Cause of Death & $\mathbf{0}-\mathbf{4}$ years & $\mathbf{5}-\mathbf{9}$ years & $\mathbf{1 0}-\mathbf{1 4}$ years & $\mathbf{1 5}-\mathbf{1 9}$ years & Total \\
\hline \hline Machinery: & & & & & \\
\hline $1982-1989$ & 2 & 2 & 2 & 3 & 8 \\
\hline $1990-1996$ & 1 & 1 & 1 & 2 & 5 \\
\hline$\%$ change & -50 & -50 & -50 & -33 & -38 \\
\hline
\end{tabular}

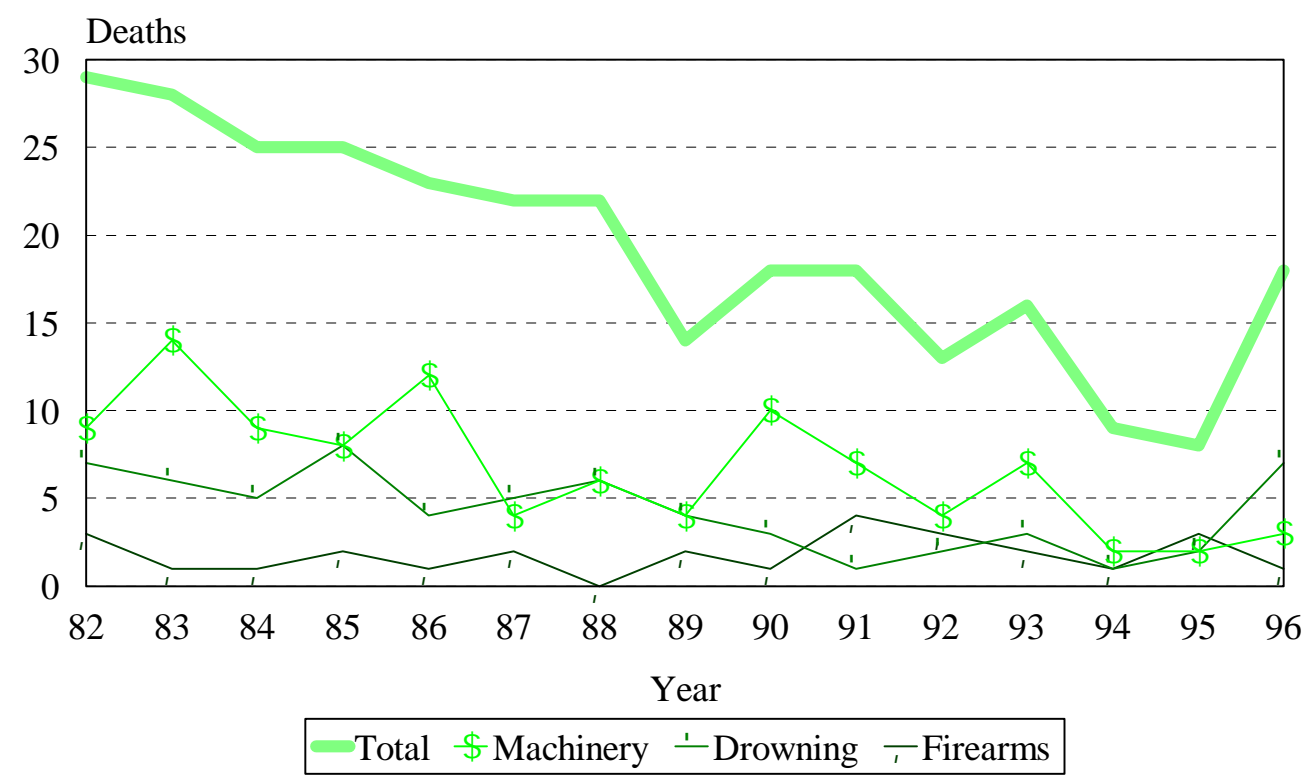

Figure 7. Trend of the leading causes of fatal farm injuries to persons less than 20 years, West Region, 1982-1996 ( $\mathrm{N}=288)$ 
Table 19. Fatal farm injuries to persons less than 20 years, by Census division and gender, United States, 1982-1996

\begin{tabular}{|l|l|c|c|c|}
\hline \multicolumn{2}{|l|}{ Census Division } & Male & Female & Total \\
\hline \hline \multirow{2}{*}{ Northeast: } & New England & 14 & 11 & 25 \\
& Middle Atlantic & 124 & 30 & 154 \\
\hline \multirow{3}{*}{ Midwest: } & East North Central & 344 & 46 & 390 \\
& West North Central & 381 & 73 & 454 \\
\hline \multirow{3}{*}{ South: } & South Atlantic & 262 & 32 & 294 \\
& East South Central & 194 & 28 & 222 \\
& West South Central & 292 & 55 & 347 \\
\hline \multirow{2}{*}{ West: } & Mountain & 154 & 29 & 183 \\
& Pacific & 88 & 17 & 105 \\
\hline Total & & 1853 & 321 & 2174 \\
\hline
\end{tabular}

Table 20. Fatal farm injuries to persons less than 20 years, by age group and Census division, United States, 1982-1996

\begin{tabular}{|l|c|c|c|c|c|}
\hline Census Division & $\mathbf{0}-\mathbf{4}$ years & $\mathbf{5}$ - 9 years & $\mathbf{1 0}$-14 years & $\mathbf{1 5}$-19 years & Total \\
\hline \hline New England & 7 & 4 & 4 & 10 & 25 \\
\hline Middle Atlantic & 51 & 26 & 37 & 40 & 154 \\
\hline East North Central & 102 & 85 & 74 & 129 & 390 \\
\hline West North Central & 126 & 93 & 94 & 141 & 454 \\
\hline South Atlantic & 43 & 54 & 83 & 114 & 294 \\
\hline East South Central & 29 & 40 & 57 & 96 & 222 \\
\hline West South Central & 75 & 68 & 77 & 127 & 347 \\
\hline Mountain & 67 & 34 & 39 & 43 & 183 \\
\hline Pacific & 27 & 17 & 19 & 42 & 105 \\
\hline Total & 527 & 421 & 484 & 742 & 2174 \\
\hline
\end{tabular}


Table 21. Causes of fatal farm injuries to persons less than 20 years, by Census division, United States, 1982-1996

\begin{tabular}{|l|c|c|c|c|c|}
\hline Cause of Death & $\begin{array}{c}\text { New } \\
\text { England }\end{array}$ & $\begin{array}{c}\text { Middle } \\
\text { Atlantic }\end{array}$ & $\begin{array}{c}\text { East North } \\
\text { Central }\end{array}$ & $\begin{array}{c}\text { West North } \\
\text { Central }\end{array}$ & $\begin{array}{c}\text { South } \\
\text { Atlantic }\end{array}$ \\
\hline \hline Machinery (E919) & 9 & 67 & 183 & 182 & 88 \\
\hline Drowning (E910) & 5 & 25 & 62 & 92 & 112 \\
\hline Firearms (E922) & 0 & 7 & 38 & 53 & 32 \\
\hline Mechanical suffocation (E911-E913) & 2 & 10 & 25 & 32 & 11 \\
\hline $\begin{array}{l}\text { Struck by or against/caught in or } \\
\text { between objects (E916-E918) }\end{array}$ & 0 & 7 & 25 & 26 & 13 \\
\hline Injury caused by animals (E905-E906) & 0 & 8 & 10 & 12 & 9 \\
\hline Electric current (E925) & 2 & 4 & 13 & 17 & 6 \\
\hline Falls (E880-E888) & 1 & 16 & 11 & 8 & 9 \\
\hline $\begin{array}{l}\text { All other causes (E850-E869, } \\
\text { E890-E899, E900-E904, E907-E909, } \\
\text { E920-E924, E928) }\end{array}$ & 3 & 8 & 23 & 32 & 12 \\
\hline $\begin{array}{l}\text { All causes of death (E850-E869 and } \\
\text { E880- E928) }\end{array}$ & 25 & 154 & 390 & 454 & 294 \\
\hline
\end{tabular}

Table 21 (Continued). Causes of fatal farm injuries to persons less than 20 years, by Census division, United States, 1982-1996

\begin{tabular}{|l|c|r|r|r|c|}
\hline Cause of Death & $\begin{array}{c}\text { South } \\
\text { Central }\end{array}$ & $\begin{array}{c}\text { West South } \\
\text { Central }\end{array}$ & Mountain & Pacific & Total \\
\hline \hline Machinery (E919) & 58 & 85 & 55 & 46 & 773 \\
\hline Drowning (E910) & 93 & 132 & 44 & 20 & 585 \\
\hline Firearms (E922) & 33 & 47 & 21 & 6 & 237 \\
\hline Mechanical suffocation (E911-E913) & 5 & 11 & 7 & 4 & 107 \\
\hline $\begin{array}{l}\text { Struck by or against/caught in or } \\
\text { between objects (E916-E918) }\end{array}$ & 10 & 8 & 13 & 7 & 109 \\
\hline Injury caused by animals (E905-E906) & 4 & 20 & 14 & 5 & 82 \\
\hline Electric current (E925) & 3 & 18 & 9 & 6 & 78 \\
\hline Falls (E880-E888) & 6 & 3 & 10 & 5 & 69 \\
\hline $\begin{array}{l}\text { All other causes (E850-E869, } \\
\text { E890-E899, E900-E904, E907-E909, } \\
\text { E920-E924, E928) }\end{array}$ & 6 & 21 & 9 & 6 & 134 \\
\hline $\begin{array}{l}\text { All causes of death (E850-E869 and } \\
\text { E880- E928) }\end{array}$ & 222 & 347 & 183 & 105 & 2174 \\
\hline
\end{tabular}




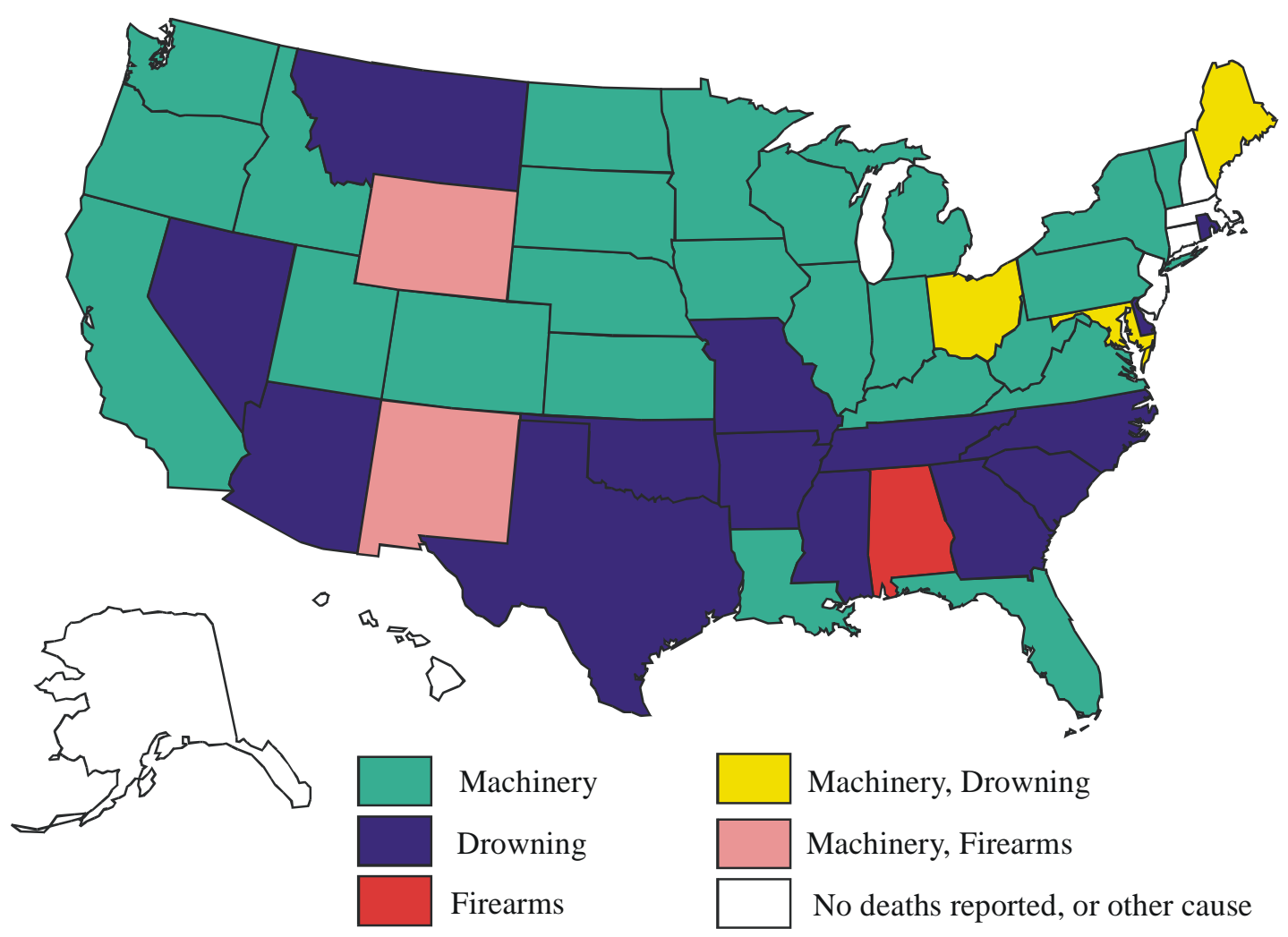

Figure 8. Leading cause of fatal farm injuries to persons less than 20 years, by state, 1982-1996

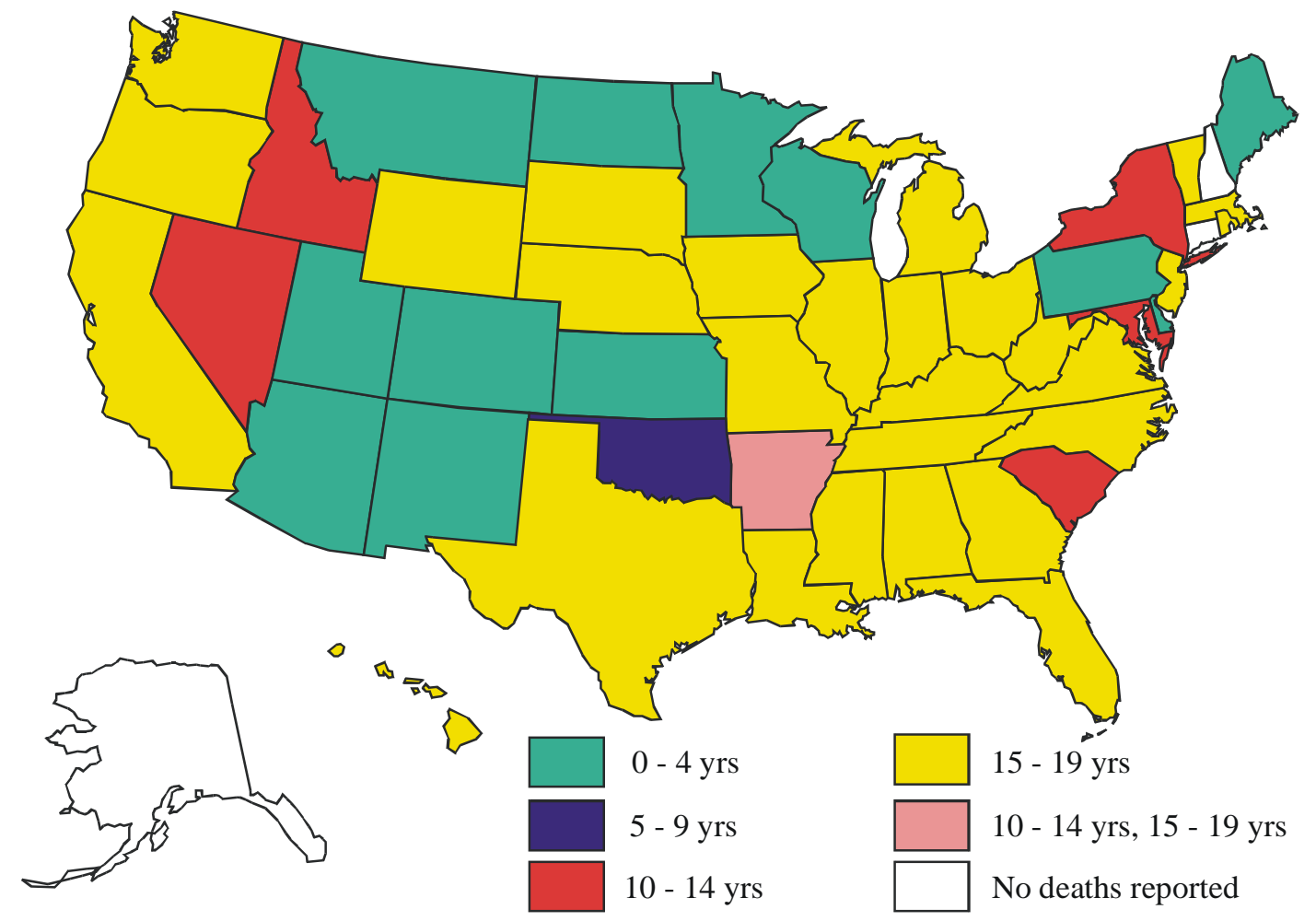

Figure 9. Age group with the highest frequency of fatal farm injuries to persons less than 20 years, by state, 1982-1996 
Table 22. Fatal farm injuries to persons less than 20 years, by age group and state, 1982-1996

\begin{tabular}{|c|c|c|c|c|c|}
\hline State & 0 - 4 years & 5 - 9 years & $10-14$ years & $15-19$ years & Total \\
\hline Alabama & 8 & 1 & 3 & 13 & 25 \\
\hline Alaska & 0 & 0 & 0 & 0 & 0 \\
\hline Arizona & 5 & 2 & 3 & 3 & 13 \\
\hline Arkansas & 8 & 10 & 17 & 17 & 52 \\
\hline California & 10 & 7 & 8 & 17 & 42 \\
\hline Colorado & 16 & 7 & 8 & 11 & 42 \\
\hline Connecticut & 0 & 0 & 0 & 0 & 0 \\
\hline Delaware & 1 & 0 & 0 & 0 & 1 \\
\hline DC & 0 & 1 & 0 & 2 & 3 \\
\hline Florida & 6 & 5 & 4 & 10 & 25 \\
\hline Georgia & 13 & 13 & 19 & 32 & 77 \\
\hline Hawaii & 0 & 0 & 0 & 1 & 1 \\
\hline Idaho & 12 & 13 & 14 & 5 & 44 \\
\hline Illinois & 17 & 17 & 14 & 27 & 75 \\
\hline Indiana & 16 & 22 & 17 & 23 & 78 \\
\hline Iowa & 25 & 22 & 27 & 33 & 107 \\
\hline Kansas & 20 & 10 & 9 & 11 & 50 \\
\hline Kentucky & 12 & 16 & 17 & 39 & 84 \\
\hline Louisiana & 2 & 3 & 5 & 15 & 25 \\
\hline Maine & 3 & 2 & 2 & 2 & 9 \\
\hline Maryland & 0 & 2 & 4 & 2 & 8 \\
\hline Massachusetts & 0 & 0 & 1 & 2 & 3 \\
\hline Michigan & 22 & 11 & 17 & 23 & 73 \\
\hline Minnesota & 25 & 17 & 21 & 14 & 77 \\
\hline Mississippi & 6 & 10 & 27 & 29 & 72 \\
\hline Missouri & 25 & 21 & 19 & 41 & 106 \\
\hline Montana & 9 & 5 & 7 & 6 & 27 \\
\hline
\end{tabular}


Table 22 (Continued). Fatal farm injuries to persons less than 20 years, by age group and state, 1982-1996

\begin{tabular}{|c|c|c|c|c|c|}
\hline State & 0 - 4 years & $5-9$ years & $10-14$ years & $15-19$ years & Total \\
\hline Nebraska & 10 & 7 & 7 & 13 & 37 \\
\hline Nevada & 1 & 1 & 2 & 1 & 5 \\
\hline New Hampshire & 0 & 0 & 0 & 0 & 0 \\
\hline New Jersey & 1 & 0 & 0 & 5 & 6 \\
\hline New Mexico & 6 & 2 & 1 & 2 & 11 \\
\hline New York & 7 & 10 & 13 & 9 & 39 \\
\hline North Carolina & 14 & 15 & 26 & 36 & 91 \\
\hline North Dakota & 8 & 3 & 3 & 5 & 19 \\
\hline Ohio & 8 & 10 & 11 & 30 & 59 \\
\hline Oklahoma & 18 & 19 & 13 & 16 & 66 \\
\hline Oregon & 11 & 6 & 6 & 15 & 38 \\
\hline Pennsylvania & 43 & 16 & 24 & 26 & 109 \\
\hline Rhode Island & 0 & 0 & 0 & 1 & 1 \\
\hline South Carolina & 2 & 5 & 17 & 13 & 37 \\
\hline South Dakota & 13 & 13 & 8 & 24 & 58 \\
\hline Tennessee & 3 & 13 & 10 & 15 & 41 \\
\hline Texas & 47 & 36 & 42 & 79 & 204 \\
\hline Utah & 11 & 2 & 3 & 6 & 22 \\
\hline Vermont & 4 & 2 & 1 & 5 & 12 \\
\hline Virginia & 4 & 9 & 10 & 11 & 34 \\
\hline Washington & 6 & 4 & 5 & 9 & 24 \\
\hline West Virginia & 3 & 4 & 3 & 8 & 18 \\
\hline Wisconsin & 39 & 25 & 15 & 26 & 105 \\
\hline Wyoming & 7 & 2 & 1 & 9 & 19 \\
\hline
\end{tabular}


Table 23. Fatal farm injuries to persons less than 20 years of age, by cause and state, 1982-1996

\begin{tabular}{|c|c|c|c|c|c|}
\hline State & Machinery & Drowning & Firearms & All other & Total \\
\hline Alabama & 6 & 5 & 7 & 7 & 25 \\
\hline Alaska & 0 & 0 & 0 & 0 & 0 \\
\hline Arizona & 1 & 6 & 1 & 5 & 13 \\
\hline Arkansas & 13 & 20 & 4 & 15 & 52 \\
\hline California & 16 & 6 & 2 & 18 & 42 \\
\hline Colorado & 11 & 8 & 3 & 20 & 42 \\
\hline Connecticut & 0 & 0 & 0 & 0 & 0 \\
\hline Delaware & 0 & 1 & 0 & 0 & 1 \\
\hline DC & 0 & 0 & 0 & 3 & 3 \\
\hline Florida & 12 & 2 & 2 & 9 & 25 \\
\hline Georgia & 19 & 31 & 10 & 17 & 77 \\
\hline Hawaii & 0 & 0 & 0 & 1 & 1 \\
\hline Idaho & 22 & 11 & 4 & 7 & 44 \\
\hline Illinois & 27 & 16 & 2 & 30 & 75 \\
\hline Indiana & 34 & 17 & 11 & 16 & 78 \\
\hline Iowa & 50 & 15 & 14 & 28 & 107 \\
\hline Kansas & 20 & 15 & 5 & 10 & 50 \\
\hline Kentucky & 34 & 22 & 11 & 17 & 84 \\
\hline Louisiana & 13 & 7 & 1 & 4 & 25 \\
\hline Maine & 3 & 3 & 0 & 3 & 9 \\
\hline Maryland & 2 & 2 & 0 & 4 & 8 \\
\hline Massachusetts & 0 & 0 & 0 & 3 & 3 \\
\hline Michigan & 34 & 7 & 9 & 23 & 73 \\
\hline Minnesota & 37 & 6 & 9 & 25 & 77 \\
\hline Mississippi & 6 & 49 & 9 & 8 & 72 \\
\hline Missouri & 29 & 39 & 14 & 24 & 106 \\
\hline Montana & 5 & 7 & 3 & 12 & 27 \\
\hline
\end{tabular}


Table 23 (Continued). Fatal farm injuries to persons less than 20 years of age, by cause and state, 1982-1996

\begin{tabular}{|c|c|c|c|c|c|}
\hline State & Machinery & Drowning & Firearms & All other & Total \\
\hline Nebraska & 15 & 2 & 3 & 17 & 37 \\
\hline Nevada & 0 & 3 & 1 & 1 & 5 \\
\hline New Hampshire & 0 & 0 & 0 & 0 & 0 \\
\hline New Jersey & 0 & 0 & 0 & 6 & 6 \\
\hline New Mexico & 3 & 2 & 3 & 3 & 11 \\
\hline New York & 20 & 5 & 2 & 12 & 39 \\
\hline North Carolina & 24 & 36 & 8 & 23 & 91 \\
\hline North Dakota & 6 & 5 & 2 & 6 & 19 \\
\hline Ohio & 17 & 17 & 8 & 17 & 59 \\
\hline Oklahoma & 15 & 32 & 4 & 15 & 66 \\
\hline Oregon & 15 & 10 & 4 & 9 & 38 \\
\hline Pennsylvania & 47 & 20 & 5 & 37 & 109 \\
\hline Rhode Island & 0 & 1 & 0 & 0 & 1 \\
\hline South Carolina & 5 & 26 & 4 & 2 & 37 \\
\hline South Dakota & 25 & 10 & 6 & 17 & 58 \\
\hline Tennessee & 12 & 17 & 6 & 6 & 41 \\
\hline Texas & 44 & 73 & 38 & 49 & 204 \\
\hline Utah & 7 & 4 & 0 & 11 & 22 \\
\hline Vermont & 6 & 1 & 0 & 5 & 12 \\
\hline Virginia & 15 & 10 & 5 & 4 & 34 \\
\hline Washington & 15 & 4 & 0 & 5 & 24 \\
\hline West Virginia & 11 & 4 & 3 & 0 & 18 \\
\hline Wisconsin & 71 & 5 & 8 & 21 & 105 \\
\hline Wyoming & 6 & 3 & 6 & 4 & 19 \\
\hline
\end{tabular}


Table 24. Leading causes of fatal farm injuries to persons less than 20 years, Alabama, 1982-1996

\begin{tabular}{|l|c|c|}
\hline Cause of Death & Frequency & Percent \\
\hline \hline Firearms (E922) & 7 & 28 \\
\hline Machinery (E919) & 6 & 24 \\
\hline Drowning (E910) & 5 & 20 \\
\hline Electric current (E925) & 3 & 12 \\
\hline All other causes (E888, E906, E909) & 4 & 16 \\
\hline All causes of death (E850-E869 and E880-E928) & 25 & 100 \\
\hline
\end{tabular}

Table 25. Leading causes of fatal farm injuries to persons less than 20 years, Arizona, 1982-1996

\begin{tabular}{|l|c|c|}
\hline Cause of Death & Frequency & Percent \\
\hline \hline Drowning (E910) & 6 & 46 \\
\hline Injury caused by animals (E905-E906) & 2 & 15 \\
\hline Electric current (E925) & 2 & 15 \\
\hline All other causes (E919, E922, E928) & 3 & 23 \\
\hline All causes of death (E850-E869 and E880-E928) & 13 & 100 \\
\hline
\end{tabular}

Table 26. Leading causes of fatal farm injuries to persons less than 20 years, Arkansas, 1982-1996

\begin{tabular}{|l|c|c|}
\hline Cause of Death & Frequency & Percent \\
\hline \hline Drowning (E910) & 20 & 38 \\
\hline Machinery (E919) & 13 & 25 \\
\hline Firearms (E922) & 4 & 7 \\
\hline Injury caused by animals (E905-E906) & 3 & 6 \\
\hline Mechanical suffocation (E911-E913) & 3 & 6 \\
\hline Struck by or against/caught in or between objects (E916-E918) & 3 & 6 \\
\hline Electric current (E925) & 3 & 6 \\
\hline All other causes (E866, E891, E907, E928) & 3 & 6 \\
\hline All causes of death (E850-E869 and E880-E928) & 52 & 100 \\
\hline
\end{tabular}


Table 27. Leading causes of fatal farm injuries to persons less than 20 years, California, 1982-1996

\begin{tabular}{|l|c|c|}
\hline Cause of Death & Frequency & Percent \\
\hline \hline Machinery (E919) & 16 & 38 \\
\hline Drowning (E910) & 6 & 14 \\
\hline Mechanical suffocation (E911-E913) & 4 & 10 \\
\hline Struck by or against/caught in or between objects (E916-E918) & 4 & 10 \\
\hline Electric current (E925) & 4 & 10 \\
\hline All other causes (E854, E868, E888, E891, E906, E922, E928) & 8 & 18 \\
\hline All causes of death (E850-E869 and E880-E928) & 42 & 100 \\
\hline
\end{tabular}

Table 28. Leading causes of fatal farm injuries to persons less than 20 years, Colorado, 1982-1996

\begin{tabular}{|l|c|c|}
\hline Cause of Death & Frequency & Percent \\
\hline \hline Machinery (E919) & 11 & 26 \\
\hline Drowning (E910) & 8 & 19 \\
\hline Falls (E880-E888) & 5 & 12 \\
\hline Struck by or against/caught in or between objects (E916-E918) & 4 & 9 \\
\hline Injury caused by animals (E905-E906) & 4 & 9 \\
\hline Firearms (E922) & 3 & 7 \\
\hline All other causes (E892, E901, E907, E913, E925) & 7 & 18 \\
\hline All causes of death (E850-E869 and E880-E928) & 42 & 100 \\
\hline
\end{tabular}

Table 29. Leading causes of fatal farm injuries to persons less than 20 years, Florida, 1982-1996

\begin{tabular}{|l|c|c|}
\hline Cause of Death & Frequency & Percent \\
\hline \hline Machinery (E919) & 12 & 48 \\
\hline Injury caused by animals (E905-E906) & 4 & 16 \\
\hline Drowning (E910) & 2 & 8 \\
\hline Firearms (E922) & 2 & 8 \\
\hline All other causes (E888, E891, E913, E918, E925) & 5 & 20 \\
\hline All causes of death (E850-E869 and E880-E928) & 25 & 100 \\
\hline
\end{tabular}


Table 30. Leading causes of fatal farm injuries to persons less than 20 years, Georgia, 1982-1996

\begin{tabular}{|l|c|c|}
\hline Cause of Death & Frequency & Percent \\
\hline \hline Drowning (E910) & 31 & 40 \\
\hline Machinery (E919) & 19 & 25 \\
\hline Firearms (E922) & 10 & 13 \\
\hline Mechanical suffocation (E911-E913) & 4 & 5 \\
\hline Falls (E880-E888) & 3 & 4 \\
\hline Struck by or against/caught in or between objects (E916-E918) & 3 & 4 \\
\hline All other causes (E868, E891, E896, E906, E925) & 7 & 9 \\
\hline All causes of death (E850-E869 and E880-E928) & 77 & 100 \\
\hline
\end{tabular}

Table 31. Leading causes of fatal farm injuries to persons less than 20 years, Idaho, 1982-1996

\begin{tabular}{|l|c|c|}
\hline Cause of Death & Frequency & Percent \\
\hline \hline Machinery (E919) & 22 & 50 \\
\hline Drowning (E910) & 11 & 25 \\
\hline Firearms (E922) & 4 & 9 \\
\hline All other causes (E892, E906, E913, E916, E918, E925) & 7 & 16 \\
\hline All causes of death (E850-E869 and E880-E928) & 44 & 100 \\
\hline
\end{tabular}

Table 32. Leading causes of fatal farm injuries to persons less than 20 years, Illinois, 1982-1996

\begin{tabular}{|l|c|c|}
\hline Cause of Death & Frequency & Percent \\
\hline \hline Machinery (E919) & 27 & 36 \\
\hline Drowning (E910) & 16 & 21 \\
\hline Mechanical suffocation (E911-E913) & 9 & 12 \\
\hline Struck by or against/caught in or between objects (E916-E918) & 5 & 7 \\
\hline Accidental poisoning (E850-E869) & 4 & 5 \\
\hline Falls (E880-E888) & 4 & 5 \\
\hline Electric current (E925) & 4 & 5 \\
\hline All other causes (E906, E921, E922, E928) & 6 & 9 \\
\hline All causes of death (E850-E869 and E880-E928) & 75 & 100 \\
\hline
\end{tabular}


Table 33. Leading causes of fatal farm injuries to persons less than 20 years, Indiana, 1982-1996

\begin{tabular}{|l|c|c|}
\hline Cause of Death & Frequency & Percent \\
\hline \hline Machinery (E919) & 34 & 44 \\
\hline Drowning (E910) & 17 & 22 \\
\hline Firearms (E922) & 11 & 14 \\
\hline Struck by or against/caught in or between objects (E916-E918) & 6 & 8 \\
\hline Mechanical suffocation (E911-E913) & 5 & 6 \\
\hline All other causes (E868, E906, E925) & 5 & 6 \\
\hline All causes of death (E850-E869 and E880-E928) & 78 & 100 \\
\hline
\end{tabular}

Table 34. Leading causes of fatal farm injuries to persons less than 20 years, Iowa, 1982-1996

\begin{tabular}{|l|c|c|}
\hline Cause of Death & Frequency & Percent \\
\hline \hline Machinery (E919) & 50 & 47 \\
\hline Drowning (E910) & 15 & 14 \\
\hline Mechanical suffocation (E911-E913) & 14 & 13 \\
\hline Firearms (E922) & 14 & 13 \\
\hline Struck by or against/caught in or between objects (E916-E918) & 4 & 4 \\
\hline All other causes (E884, E894, E901, E906, E908, E924, E925, E928) & 10 & 9 \\
\hline All causes of death (E850-E869 and E880-E928) & 107 & 100 \\
\hline
\end{tabular}

Table 35. Leading causes of fatal farm injuries to persons less than 20 years, Kansas, 1982-1996

\begin{tabular}{|l|c|c|}
\hline Cause of Death & Frequency & Percent \\
\hline \hline Machinery (E919) & 20 & 40 \\
\hline Drowning (E910) & 15 & 30 \\
\hline Firearms (E922) & 5 & 10 \\
\hline Struck by or against/caught in or between objects (E916-E918) & 3 & 6 \\
\hline Electric current (E925) & 3 & 6 \\
\hline All other causes (E884, E888, E912, E920, E928) & 4 & 8 \\
\hline All causes of death (E850-E869 and E880-E928) & 50 & 100 \\
\hline
\end{tabular}


Table 36. Leading causes of fatal farm injuries to persons less than 20 years, Kentucky, 1982-1996

\begin{tabular}{|l|c|c|}
\hline Cause of Death & Frequency & Percent \\
\hline \hline Machinery (E919) & 34 & 40 \\
\hline Drowning (E910) & 22 & 26 \\
\hline Firearms (E922) & 11 & 13 \\
\hline Struck by or against/caught in or between objects (E916-E918) & 5 & 6 \\
\hline Explosive material (E923) & 4 & 5 \\
\hline Mechanical suffocation (E911-E913) & 3 & 4 \\
\hline All other causes (E888, E894, E906, E920, E928) & 5 & 6 \\
\hline All causes of death (E850-E869 and E880-E928) & 84 & 100 \\
\hline
\end{tabular}

Table 37. Leading causes of fatal farm injuries to persons less than 20 years, Louisiana, 1982-1996

\begin{tabular}{|l|c|c|}
\hline Cause of Death & Frequency & Percent \\
\hline \hline Machinery (E919) & 13 & 52 \\
\hline Drowning (E910) & 7 & 28 \\
\hline All other causes (E888, E906, E922, E925) & 5 & 20 \\
\hline All causes of death (E850-E869 and E880-E928) & 25 & 100 \\
\hline
\end{tabular}

Table 38. Leading causes of fatal farm injuries to persons less than 20 years, Michigan, 1982-1996

\begin{tabular}{|l|c|c|}
\hline Cause of Death & Frequency & Percent \\
\hline \hline Machinery (E919) & 34 & 47 \\
\hline Firearms (E922) & 9 & 12 \\
\hline Drowning (E910) & 7 & 10 \\
\hline Nature/environment (E900-E904, E907-E909) & 4 & 5 \\
\hline Mechanical suffocation (E911-E913) & 4 & 5 \\
\hline Struck by or against/caught in or between objects (E916-E918) & 4 & 5 \\
\hline Injury caused by animals (E905-E906) & 3 & 4 \\
\hline Electric current (E925) & 3 & 4 \\
\hline All other causes (E862, E883, E884, E891) & 5 & 7 \\
\hline All causes of death (E850-E869 and E880-E928) & 73 & 100 \\
\hline
\end{tabular}


Table 39. Leading causes of fatal farm injuries to persons less than 20 years, Minnesota, 1982-1996

\begin{tabular}{|l|c|c|}
\hline Cause of Death & Frequency & Percent \\
\hline \hline Machinery (E919) & 37 & 48 \\
\hline Firearms (E922) & 9 & 12 \\
\hline Mechanical suffocation (E911-E913) & 7 & 9 \\
\hline Drowning (E910) & 6 & 8 \\
\hline Nature/environment (E900-E904, E907-E909) & 4 & 5 \\
\hline Struck by or against/caught in or between objects (E916-E918) & 4 & 5 \\
\hline Electric current (E925) & 4 & 5 \\
\hline Injury caused by animals (E905-E906) & 3 & 4 \\
\hline All other causes (E864, E920, E925, E928) & 3 & 4 \\
\hline All causes of death (E850-E869 and E880-E928) & 77 & 100 \\
\hline
\end{tabular}

Table 40. Leading causes of fatal farm injuries to persons less than 20 years, Mississippi, 1982-1996

\begin{tabular}{|l|c|c|}
\hline Cause of Death & Frequency & Percent \\
\hline \hline Drowning (E910) & 49 & 68 \\
\hline Firearms (E922) & 9 & 13 \\
\hline Machinery (E919) & 6 & 8 \\
\hline Struck by or against/caught in or between objects (E916-E918) & 3 & 4 \\
\hline All other causes (E868, E883, E884, E906, E913, E928) & 5 & 7 \\
\hline All causes of death (E850-E869 and E880-E928) & 72 & 100 \\
\hline
\end{tabular}


Table 41. Leading causes of fatal farm injuries to persons less than 20 years, Missouri, 1982-1996

\begin{tabular}{|l|c|c|}
\hline Cause of Death & Frequency & Percent \\
\hline \hline Drowning (E910) & 39 & 37 \\
\hline Machinery (E919) & 29 & 27 \\
\hline Firearms (E922) & 14 & 13 \\
\hline Nature/environment (E900-E904, E907-E909) & 5 & 5 \\
\hline Injury caused by animals (E905-E906) & 5 & 5 \\
\hline Mechanical suffocation (E911-E913) & 5 & 5 \\
\hline Falls (E880-E888) & 4 & 4 \\
\hline All other causes (E891, E916, E925) & 5 & 5 \\
\hline All causes of death (E850-E869 and E880-E928) & 106 & 100 \\
\hline
\end{tabular}

Table 42. Leading causes of fatal farm injuries to persons less than 20 years, Montana, 1982-1996

\begin{tabular}{|l|c|c|}
\hline Cause of Death & Frequency & Percent \\
\hline \hline Drowning (E910) & 7 & 26 \\
\hline Machinery (E919) & 5 & 19 \\
\hline Struck by or against/caught in or between objects (E916-E918) & 3 & 11 \\
\hline Firearms (E922) & 3 & 11 \\
\hline All other causes (E888, E906, E909, E913, E925) & 9 & 33 \\
\hline All causes of death (E850-E869 and E880-E928) & 27 & 100 \\
\hline
\end{tabular}

Table 43. Leading causes of fatal farm injuries to persons less than 20 years, Nebraska, 1982-1996

\begin{tabular}{|l|c|c|}
\hline Cause of Death & Frequency & Percent \\
\hline \hline Machinery (E919) & 15 & 41 \\
\hline Struck by or against/caught in or between objects (E916-E918) & 7 & 19 \\
\hline Electric current (E925) & 4 & 11 \\
\hline Firearms (E922) & 3 & 8 \\
\hline All other causes (E888, E906, E909, E910, E913, E928) & 8 & 21 \\
\hline All causes of death (E850-E869 and E880-E928) & 37 & 100 \\
\hline
\end{tabular}


Table 44. Leading causes of fatal farm injuries to persons less than 20 years, New Mexico, 1982-1996

\begin{tabular}{|l|c|c|}
\hline Cause of Death & Frequency & Percent \\
\hline \hline Machinery (E919) & 3 & 27 \\
\hline Firearms (E922) & 3 & 27 \\
\hline All other causes (E888, E906, E909, E910) & 5 & 46 \\
\hline All causes of death (E850-E869 and E880-E928) & 11 & 100 \\
\hline
\end{tabular}

Table 45. Leading causes of fatal farm injuries to persons less than 20 years, New York, 1982-1996

\begin{tabular}{|l|c|c|}
\hline Cause of Death & Frequency & Percent \\
\hline \hline Machinery (E919) & 20 & 51 \\
\hline Drowning (E910) & 5 & 13 \\
\hline Injury caused by animals (E905-E906) & 3 & 8 \\
\hline Struck by or against/caught in or between objects (E916-E918) & 2 & 5 \\
\hline Firearms (E922) & 2 & 5 \\
\hline Electric current (E925) & 2 & 5 \\
\hline All other causes (E869, E888, E891, E913) & 5 & 13 \\
\hline All causes of death (E850-E869 and E880-E928) & 39 & 100 \\
\hline
\end{tabular}

Table 46. Leading causes of fatal farm injuries to persons less than 20 years, North Carolina, 1982-1996

\begin{tabular}{|l|c|c|}
\hline Cause of Death & Frequency & Percent \\
\hline \hline Drowning (E910) & 36 & 40 \\
\hline Machinery (E919) & 24 & 26 \\
\hline Firearms (E922) & 8 & 9 \\
\hline Mechanical suffocation (E911-E913) & 5 & 6 \\
\hline Struck by or against/caught in or between objects (E916-E918) & 5 & 6 \\
\hline Electric current (E925) & 3 & 3 \\
\hline All other causes (E863, E884, E888, E906, E907) & 10 & 10 \\
\hline All causes of death (E850-E869 and E880-E928) & 91 & 100 \\
\hline
\end{tabular}


Table 47. Leading causes of fatal farm injuries to persons less than 20 years, North Dakota, 1982-1996

\begin{tabular}{|l|c|c|}
\hline Cause of Death & Frequency & Percent \\
\hline \hline Machinery (E919) & 6 & 31 \\
\hline Drowning (E910) & 5 & 26 \\
\hline Struck by or against/caught in or between objects (E916-E918) & 3 & 16 \\
\hline All other causes (E909, E913, E922) & 5 & 26 \\
\hline All causes of death (E850-E869 and E880-E928) & 19 & 100 \\
\hline
\end{tabular}

Table 48. Leading causes of fatal farm injuries to persons less than 20 years, Ohio, 1982-1996

\begin{tabular}{|c|c|c|}
\hline Cause of Death & Frequency & Percent \\
\hline Drowning (E910) & 17 & 29 \\
\hline Machinery (E919) & 17 & 29 \\
\hline Firearms (E922) & 8 & 14 \\
\hline Struck by or against/caught in or between objects (E916-E918) & 5 & 8 \\
\hline Electric current (E925) & 3 & 5 \\
\hline All other causes (E862, E888, E892, E906, E909, E913, E928) & 9 & 15 \\
\hline All causes of death (E850-E869 and E880-E928) & 59 & 100 \\
\hline
\end{tabular}

Table 49. Leading causes of fatal farm injuries to persons less than 20 years, Oklahoma, 1982-1996

\begin{tabular}{|l|c|c|}
\hline Cause of Death & Frequency & Percent \\
\hline \hline Drowning (E910) & 32 & 48 \\
\hline Machinery (E919) & 15 & 23 \\
\hline Injury caused by animals (E905-E906) & 6 & 9 \\
\hline Firearms (E922) & 4 & 6 \\
\hline All other causes (E899, E913, E917, E925, E928) & 9 & 14 \\
\hline All causes of death (E850-E869 and E880-E928) & 66 & 100 \\
\hline
\end{tabular}


Table 50. Leading causes of fatal farm injuries to persons less than 20 years, Oregon, 1982-1996

\begin{tabular}{|l|c|c|}
\hline Cause of Death & Frequency & Percent \\
\hline \hline Machinery (E919) & 15 & 39 \\
\hline Drowning (E910) & 10 & 26 \\
\hline Firearms (E922) & 4 & 11 \\
\hline Struck by or against/caught in or between objects (E916-E918) & 3 & 8 \\
\hline All other causes (E869, E888, E906, E925, E928) & 6 & 16 \\
\hline All causes of death (E850-E869 and E880-E928) & 38 & 100 \\
\hline
\end{tabular}

Table 51. Leading causes of fatal farm injuries to persons less than 20 years, Pennsylvania, 1982-1996

\begin{tabular}{|l|c|c|}
\hline Cause of Death & Frequency & Percent \\
\hline \hline Machinery (E919) & 47 & 43 \\
\hline Drowning (E910) & 20 & 18 \\
\hline Falls (E880-E888) & 13 & 12 \\
\hline Mechanical suffocation (E911-E913) & 8 & 7 \\
\hline Struck by or against/caught in or between objects (E916-E918) & 5 & 5 \\
\hline Firearms (E922) & 5 & 5 \\
\hline Accidental poisoning (E850-E869) & 3 & 3 \\
\hline Injury caused by animals (E905-E906) & 3 & 3 \\
\hline All other causes (E923, E925, E928) & 5 & 5 \\
\hline All causes of death (E850-E869 and E880-E928) & 109 & 100 \\
\hline
\end{tabular}

Table 52. Leading causes of fatal farm injuries to persons less than 20 years, South Carolina, 1982-1996

\begin{tabular}{|l|c|c|}
\hline Cause of Death & Frequency & Percent \\
\hline \hline Drowning (E910) & 26 & 70 \\
\hline Machinery (E919) & 5 & 14 \\
\hline Firearms (E922) & 4 & 11 \\
\hline All other causes (E909, E928) & 2 & 5 \\
\hline All causes of death (E850-E869 and E880-E928) & 37 & 100 \\
\hline
\end{tabular}


Table 53. Leading causes of fatal farm injuries to persons less than 20 years, South Dakota, 1982-1996

\begin{tabular}{|l|c|c|}
\hline Cause of Death & Frequency & Percent \\
\hline \hline Machinery (E919) & 25 & 43 \\
\hline Drowning (E910) & 10 & 17 \\
\hline Firearms (E922) & 6 & 10 \\
\hline Nature/environment (E900-E904, E907-E909) & 3 & 5 \\
\hline Mechanical suffocation (E911-E913) & 3 & 5 \\
\hline Struck by or against/caught in or between objects (E916-E918) & 3 & 5 \\
\hline All other causes (E860, E869, E906, E920, E925, E928) & 8 & 14 \\
\hline All causes of death (E850-E869 and E880-E928) & 58 & 100 \\
\hline
\end{tabular}

Table 54. Leading causes of fatal farm injuries to persons less than 20 years, Tennessee, 1982-1996

\begin{tabular}{|l|c|c|}
\hline Cause of Death & Frequency & Percent \\
\hline \hline Drowning (E910) & 17 & 41 \\
\hline Machinery (E919) & 12 & 29 \\
\hline Firearms (E922) & 6 & 15 \\
\hline All other causes (E884, E887, E891, E913, E916, E917, E928) & 6 & 15 \\
\hline All causes of death (E850-E869 and E880-E928) & 41 & 100 \\
\hline
\end{tabular}


Table 55. Leading causes of fatal farm injuries to persons less than 20 years, Texas, 1982-1996

\begin{tabular}{|l|c|c|}
\hline Cause of Death & Frequency & Percent \\
\hline \hline Drowning (E910) & 73 & 36 \\
\hline Machinery (E919) & 44 & 22 \\
\hline Firearms (E922) & 38 & 19 \\
\hline Electric current (E925) & 12 & 6 \\
\hline Injury caused by animals (E905-E906) & 9 & 4 \\
\hline Nature/environment (E900-E904, E907-E909) & 7 & 3 \\
\hline Mechanical suffocation (E911-E913) & 6 & 3 \\
\hline Struck by or against/caught in or between objects (E916-E918) & 4 & 2 \\
\hline Fire \& flames (E890-E899) & 3 & 1 \\
\hline All other causes (E862, E882, E888, E921, E923, E928) & 8 & 4 \\
\hline All causes of death (E850-E869 and E880-E928) & 204 & 100 \\
\hline
\end{tabular}

Table 56. Leading causes of fatal farm injuries to persons less than 20 years, Utah, 1982-1996

\begin{tabular}{|l|c|c|}
\hline Cause of Death & Frequency & Percent \\
\hline \hline Machinery (E919) & 7 & 32 \\
\hline Drowning (E910) & 4 & 18 \\
\hline All other causes (E888, E906, E909, E913, E918, E925) & 11 & 50 \\
\hline All causes of death (E850-E869 and E880-E928) & 22 & 100 \\
\hline
\end{tabular}

Table 57. Leading causes of fatal farm injuries to persons less than 20 years, Vermont, 1982-1996

\begin{tabular}{|l|c|c|}
\hline Cause of Death & Frequency & Percent \\
\hline \hline Machinery (E919) & 6 & 50 \\
\hline Drowning (E910) & 1 & 8 \\
\hline All other causes (E909, E913, E925, E928) & 5 & 42 \\
\hline All causes of death (E850-E869 and E880-E928) & 12 & 100 \\
\hline
\end{tabular}


Table 58. Leading causes of fatal farm injuries to persons less than 20 years, Virginia, 1982-1996

\begin{tabular}{|l|c|c|}
\hline Cause of Death & Frequency & Percent \\
\hline \hline Machinery (E919) & 15 & 44 \\
\hline Drowning (E910) & 10 & 29 \\
\hline Firearms (E922) & 5 & 15 \\
\hline Struck by or against/caught in or between objects (E916-E918) & 3 & 9 \\
\hline Mechanical suffocation (E911-E913) & 1 & 3 \\
\hline All causes of death (E850-E869 and E880-E928) & 34 & 100 \\
\hline
\end{tabular}

Table 59. Leading causes of fatal farm injuries to persons less than 20 years, Washington, 1982-1996

\begin{tabular}{|l|c|c|}
\hline Cause of Death & Frequency & Percent \\
\hline \hline Machinery (E919) & 15 & 63 \\
\hline Drowning (E910) & 4 & 17 \\
\hline Injury by animals (E905-E906) & 3 & 12 \\
\hline Falls (E880-E888) & 2 & 8 \\
\hline All causes of death (E850-E869 and E880-E928) & 24 & 100 \\
\hline
\end{tabular}

Table 60. Leading causes of fatal farm injuries to persons less than 20 years, West Virginia, 1982-1996

\begin{tabular}{|l|c|c|}
\hline Cause of Death & Frequency & Percent \\
\hline \hline Machinery (E919) & 11 & 61 \\
\hline Drowning (E910) & 4 & 22 \\
\hline Firearms (E922) & 3 & 17 \\
\hline All causes of death (E850-E869 and E880-E928) & 18 & 100 \\
\hline
\end{tabular}


Table 61. Leading causes of fatal farm injuries to persons less than 20 years, Wisconsin, 1982-1996

\begin{tabular}{|l|c|c|}
\hline Cause of Death & Frequency & Percent \\
\hline \hline Machinery (E919) & 71 & 67 \\
\hline Firearms (E922) & 8 & 7 \\
\hline Mechanical suffocation (E911-E913) & 6 & 6 \\
\hline Drowning (E910) & 5 & 5 \\
\hline Struck by or against/caught in or between objects (E916-E918) & 5 & 5 \\
\hline Falls (E880-E888) & 4 & 4 \\
\hline All other causes (E906, E920, E923, E925) & 6 & 6 \\
\hline All causes of death (E850-E869 and E880-E928) & 105 & 100 \\
\hline
\end{tabular}

Table 62. Leading causes of fatal farm injuries to persons less than 20 years, Wyoming, 1982-1996

\begin{tabular}{|l|c|c|}
\hline Cause of Death & Frequency & Percent \\
\hline \hline Machinery (E919) & 6 & 31 \\
\hline Firearms (E922) & 6 & 31 \\
\hline Drowning (E910) & 3 & 16 \\
\hline All other causes (E906, E918, E925) & 4 & 21 \\
\hline All causes of death (E850-E869 and E880-E928) & 19 & 100 \\
\hline
\end{tabular}





\section{Appendix}

\section{Classification of External Causes of Unintentional Deaths*}

\begin{tabular}{|l|l|}
\hline Cause of Death & E-code \\
\hline \hline Poisoning & $850-869$ \\
\hline Falls & $880-888$ \\
\hline Fire \& flames & $890-899$ \\
\hline Nature/environment & $900-904,907-909$ \\
\hline Injury caused by animals & $905-906$ \\
\hline Drowning & 910 \\
\hline Mechanical suffocation & $911-913$ \\
\hline Struck by or against/caught in or between objects & $916-918$ \\
\hline Machinery & 919 \\
\hline Cutting and piercing instruments or objects & 920 \\
\hline Explosion of pressure vessel & 921 \\
\hline Firearms & 922 \\
\hline Explosive material & 923 \\
\hline Hot substance or object, caustic or corrosive material and steam & 924 \\
\hline Electric current & 925 \\
\hline Other unspecified causes, e.g., noise, vibration, etc. & 928 \\
\hline
\end{tabular}

${ }^{*}$ International Classification of Diseases, $9^{\text {th }}$ Revision. 